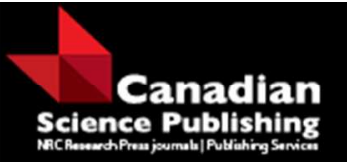

Canadian Journal of Forest Research Revue canadienne de recherche forestière

\title{
Bottom-up factors contribute to large-scale synchrony in spruce budworm populations
}

\begin{tabular}{|r|l|}
\hline Journal: & Canadian Journal of Forest Research \\
\hline Manuscript ID & cjfr-2017-0051.R2 \\
\hline Manuscript Type: & Article \\
\hline Date Submitted by the Author: & 06-Jun-2017 \\
\hline Complete List of Authors: & $\begin{array}{l}\text { Bouchard, Mathieu; Gouvernement du Quebec, Ministère de la Forêt, de la } \\
\text { Faune et des Parcs } \\
\text { Régnière, Jacques; Natural Resources Canada } \\
\text { Therrien, Pierre; Gouvernement du Quebec, Ministère de la Forêt, de la } \\
\text { Faune et des Parcs }\end{array}$ \\
\hline Keyword: & $\begin{array}{l}\text { Spruce budworm, Population synchrony, Mast years, Boreal forests, } \\
\text { Phenology }\end{array}$ \\
\hline $\begin{array}{r}\text { Is the invited manuscript for } \\
\text { consideration in a Special } \\
\text { Issue? : }\end{array}$ & IUFRO 2016 Special Issue \\
\hline \multicolumn{2}{|c}{} \\
\hline
\end{tabular}




\section{Bottom-up factors contribute to large-scale synchrony in spruce budworm populations}

2 Mathieu Bouchard, Direction de la Recherche Forestière, Ministère des Forêts, de la Faune et des Parcs

3 du Québec, 2700 rue Einstein, Québec, QC, Canada G1P 3W8. E-mail:

$4 \quad$ Mathieu.Bouchard@mffp.gouv.qc.ca

5 Jacques Régnière, Natural Resources Canada, Canadian Forest Service, Laurentian Forestry Centre, PO

6 Box 10380 Stn. Ste Foy, Quebec, Canada G1V 4C4. E-mail : Jacques.Regniere@Canada.ca

7 Pierre Therrien, Direction de la Protection des Forêts, Ministère des Forêts, de la Faune et des Parcs du

8 Québec, 2700 rue Einstein, Québec, QC, Canada G1P 3W8. E-mail: Pierre.Therrien@mffp.gouv.qc.ca

9 Abstract

10 Understanding the mechanisms that cause large-scale synchrony in insect population dynamics might

11 yield key insights for predicting potential outbreak occurrence. Here, we evaluated which environmental

12 factors best explain synchronous population fluctuations in the spruce budworm (SBW), a major

13 defoliator of coniferous forests in North-America. SBW population levels were assessed with pheromone

14 traps during the $1986-2014$ period across a $625,000 \mathrm{~km}^{2}$ territory located in the province of Québec

15 (Canada). The populations were characterized by abundance fluctuations that were often synchronized

16 across the whole study area. Interannual population fluctuations were correlated with host tree cone

17 production (mast years) and high May temperatures, suggesting that synchrony was influenced by food

18 availability and phenological mismatch during shoot development. Cone production was itself correlated

19 with low precipitation during the previous summer. This study indicates that bottom-up trophic factors

20 can drive spatiotemporal synchrony in insect populations, and contribute to explain important and

21 sustained population increases during some years. We also suggest that several biological processes, all

22 influenced by weather, are likely to interact to explain population synchrony during the different phases

23 of the ca. 35 years SBW outbreak cycle, complicating the prediction of climate change effects on this

24 insect. 


\section{Résumé}

26 La compréhension des mécanismes qui causent le synchronisme à grande échelle dans la dynamique des

27 populations d'insectes pourrait aider à mieux prédire l'occurrence d'épidémies. Dans cette étude, nous

28 avons évalué quels facteurs environnementaux expliquent le mieux les fluctuations synchrones de

29 populations de tordeuse des bourgeons de l'épinette (TBÉ), un défoliateur important des forêts

30 conifériennes d'Amérique du Nord. Les niveaux de populations de TBÉ ont été évalués à l'aide de pièges

31 à phéromones durant la période1986-2014 dans un territoire de $625000 \mathrm{~km}^{2}$ localisé dans la province de

32 Québec (Canada). Les populations de TBÉ étaient caractérisées par des fluctuations d'abondance qui

33 étaient souvent synchronisées sur l'ensemble du territoire. Les fluctuations interannuelles de populations

34 étaient corrélées avec la production semencière des arbres hôtes (un substrat alimentaire) et des

35 températures élevées lors du mois de mai, suggérant que le synchronisme était influencé par la

36 disponibilité en nourriture et le décalage phénologique lors du débourrement. La production semencière

37 était elle-même corrélée avec un faible niveau de précipitations durant l'été précédent. Cette étude

38 indique que la disponibilité en ressources peut expliquer le synchronisme spatio-temporel chez les

39 populations d'insectes, et contribue à expliquer des hausses de populations importantes et soutenues lors

40 de certaines années. Nous suggérons également que plusieurs processus biologiques, tous influencés par

41 les conditions météorologiques, pourraient interagir pour expliquer la synchronisation lors de différentes

42 phases du cycle épidémique de la TBÉ, compliquant la prédiction des effets des changements climatiques

43 sur cet insecte. 


\section{Introduction}

Large-scale synchrony in population fluctuations has been described for many animal species, including small mammals, ungulates and particularly insects (Liebhold et al. 2012, Myers and Cory 2013). Synchronous population increases have also been hypothesized to contribute to insect outbreak occurrence, for example by facilitating escape from natural enemy control (Liebhold et al. 2012). Population synchrony can take place across vast spatial scales (e.g., $>100 \mathrm{~km}$ ), and is often thought to correlate with climatic perturbations, i.e., the so-called 'Moran effect' (Moran 1953). However, the exact causal pathways through which climate and weather synchronize demography across large areas are still poorly understood. The mechanism that have been proposed are varied, and range from a direct effect of weather on animal populations, to indirect effects through bottom-up and top-down factors, or dispersalrelated factors (Liebhold et al. 2012).

The spruce budworm (Choristoneura fumiferana Clem.; SBW) outbreak system represents an interesting opportunity to explore the causal relationships that can explain synchronous population fluctuations across large spatial scales. The spruce budworm is a defoliator of Abies spp. and Picea spp. in North American boreal forests. In eastern Canada, SBW outbreaks have occurred every 30-40 years for the last two centuries at least, and these cycles tend to be loosely synchronized at the regional level (Royama 1984, Williams and Liebhold 2000, Morin et al. 2007). Cumulative defoliation by this insect results in substantial tree mortality, and has cascading effects in boreal forest ecosystems (Bouchard et al. 2006). SBW population dynamics are driven by several processes such as competition for food, disease propagation, predation, parasitism and migration (Régnière 1984, Royama 1984, Régnière and Nealis 2007). Some causal mechanisms have been proposed to explain large-scale synchrony, such as temporal variation in apparent fecundity and natural enemies (Royama 1984) or moth dispersal (Régnière and Lysyk 1995, Royama et al. 2005), but these hypotheses were not examined over large spatial scales, and connections between year-to-year weather fluctuations and specific SBW population processes remain little explored. 
Temporal variation in feeding substrate availability could be important to explain spatial

72 synchrony in insect populations. For example, in the case of the gypsy moth (Lymantria dispar), it has

73 been suggested that episodic acorn production by oak trees could ultimately explain large-scale

74 synchronous outbreak occurrence (Haynes et al. 2013). In this case, acorn abundance affects the white-

75 footed mouse (Peromyscus leucopus), a predator of the gypsy moth, and the trophic relationship could

76 thus be better described as top-down than bottom-up (Haynes et al. 2013). In geometrid outbreaks in

77 Norway, Jepsen et al. (2009) found that the degree of synchrony between egg hatch and bud development

78 in the spring influences large-scale synchronization. Similarly, temporal variation in food quality was

79 found to be important for spatial synchrony in the jack pine budworm (Choristoneura pinus pinus), a

80 species that is closely related to the SBW. Short-duration outbreaks in this insect were associated with

81 pollen cone production episodes in its host species, jack pine (Pinus banksiana) (Nealis 2003). For the

82 SBW, the potential importance of balsam fir pollen cone availability for outbreak occurrence has been

83 suggested in a few studies (Blais 1952, Morris 1963). This resource constitutes an easily accessible and

84 nutritious food source in early spring, and provides a favorable micro-habitat for larvae emerging from

overwintering (Carisey and Bauce 1997). Pollen cones can alleviate the negative impact of phenological

mismatch between the insect and host tree shoot development, known to be highly variable in space and

87 time depending on early spring conditions (Greenbank 1963a, Nealis and Lomic 1994), and could

88 therefore have important repercussions on the insect's population dynamics.

It is uncertain to what extent a large-scale synchronous increase in population density during a

90 given year can persist during subsequent years. Density-dependent factors such as natural enemies or

91 resource scarcity during the years following the increase are susceptible to drive insect populations back

92 to pre-increase levels. Still, under some conditions, higher densities could persist over several years. In

93 the case of the SBW, low-density populations can be subjected to mate-finding difficulties (Régnière et

94 al. 2013a), which could generate a positive relationship between population density and population

95 growth. Also, in insects, the likelihood that natural enemies are able to aggregate to supress host 
96 populations is generally inversely related to the spatial extent and spatial homogeneity of the host

97 population increases (Briggs and Hoopes 2004), suggesting that large-scale increases are also more likely

98 to persist over time. Finally, the SBW also possesses foraging capabilities that allow it to cope with

99 resource scarcity during less favorable years, for example by mining or feeding upon older foliage when

100 optimal feeding substrates such as very young foliage or pollen cones are not available (Lawrence et al.

101 1997). Hence, population increases caused by large-scale pulses of resource during one year could

102 potentially persist over subsequent years, leading to rising SBW populations and outbreak initiation in

103 some cases.

The main goal of this study was to clarify the causal pathways between environmental variability and large-scale fluctuations in insect populations, and if these fluctuations could lead to persistent population increases. The SBW system, which has been thoroughly monitored over the years and for

107 which an abundance of data has been collected, provides an ideal opportunity to look at these processes. Specifically, in this study, we examined whether regional-scale fluctuations in SBW populations were likely to be explained by variables associated directly or indirectly with weather, including synchronous host tree cone production.

\section{Methods}

112 Data sources. The study took place in the province of Québec (Canada), in an area approximately $113625,000 \mathrm{~km}^{2}$ in size (Figure 1). Annual variation in SBW abundance across the study area (Fig. 1) was 114 quantified with pheromone trap catch data from 1986-2014. Nonsaturating Multi-Pher traps (Distributions 115 Solida Inc., Saint-Ferréol-les-Neiges, QC) baited with spruce budworm pheromone were used to capture 116 males. The type of commercial lure that was used in the traps changed over the years; it included PVC 117 lures (manufactured by the New Brunswick Research and Productivity Council) between 1986 and 1989 , 118 Biolure (2.8 mg load of pheromone released from a permeable membrane; Suterra Inc., Bend, OR) 119 between 1990 and 2010, and Flexlure (3.3 mg load of pheromone released from small PVC cylinders; 
120 Contech Enterprises Inc., Victoria, BC) from 2011-2014. Each time the lure type was changed, calibration

121 was done to make sure that effectiveness was as comparable as possible across years (Sanders 1996,

122 Rhainds et al. 2016).

123 Traps were set up before the moth flight period and collected in the fall to determine the number

124 of moths that were caught. A strip of insecticide (Vaportape II, Hercon Environmental, Emigsville, PA)

125 was placed at the bottom of the traps to kill captured moths. The traps were placed in plots located across

126 the province (Fig. 1) and operated yearly. Three traps were placed in each plot, located $40 \mathrm{~m}$ apart in a

127 triangle, at a height of $2 \mathrm{~m}$ on balsam fir trees. In further analyses, moth captures per trap were averaged

128 for each plot, and averaged again in each cells of a 1 X 1 degree grid covering the entire study area.

129 Pooling data at the cell level was done to make sure that locations where a higher density of traps was

130 installed for one reason or another were not given more weight in the analyses explaining spatial

131 synchrony. Cell-level information on SBW populations, including the number of traps and mean moth

132 abundance per cell, is presented in Supplementary Materials 1 and 2.

Balsam fir pollen cones are an important feeding substrate for the SBW. The abundance of

134 conifer pollen cones varies from year to year, depending on the occurrence of mast years, and tends to be

135 correlated across large areas (Koenig 2002). Annual variation in pollen cone abundance was estimated

136 using 1986-2014 seed collection data from provincial authorities. Seed collection is done annually in

137 natural forests and seed orchards located across the province to provide seeds for tree nurseries. Data

138 were more consistent and reliable for white spruce (Picea glauca) than for balsam fir, because this species

139 is well represented throughout the province and is in high demand for tree planting (and thus more closely

140 monitored by seed collectors). Cone production is known to be highly correlated among conifers,

141 including between white spruce and balsam fir (Rossi et al. 2012), and between male and female cones in

142 conifers in general (Moreira et al. 2014). Therefore, we used white spruce seed abundance as an estimate

143 of annual variation in host tree cone production (Supplementary material 3). A semi-quantitative metric

144 was used to assess cone production: null (0), low (1), moderate (2), high (3) and exceptional (4) 
145 abundance. The mast years identified using this method were also validated by looking at independent 146 field studies conducted across the province (Bauce and Carisey 1996, Houle 1999, Robert et al. 2012, 147 Rossi et al. 2012).

Weather is important with respect to its effect on local SBW populations, but the potential effects 149 of annual variation in weather on landscape-level SBW population synchrony have never been examined. 150 Summary weather variables that are potentially important to predict SBW development were obtained for 151 each cell of the $1 \times 1$ degree grid covering the area where pheromone trap information was available.

152 Meteorological information was interpolated from the eight weather stations nearest to the center of each cell with BioSIM (Régnière et al. 2013b). The effects of weather on SBW were quantified using three 154 indices. First, we used total precipitation and total degree-days above $5^{\circ} \mathrm{C}$ in May. This period coincides with the emergence of overwintering larvae. During this period, the larvae are very small (second or third instar), and they can be affected by weather in multiple ways, including through synchrony with host tree

157 shoot development, exposure to extreme weather (rainstorms), or dispersal-related mortality (Rose and Blais 1954, Greenbank 1963a). Second, the mean maximum daily temperature during the flight period was calculated. High evening temperatures during the flight period (from late June to late July) could enhance SBW moth flight activity (Sanders et al. 1978) and influence population abundance estimated

161 from pheromone trap captures. Finally, we determined the ordinal date that corresponded to the peak of 162 egg hatch during the previous year, just before the beginning of larval diapause in late summer. Hatching 163 that occurs too late in the season can cause high winter mortality (Régnière et al. 2012) and, therefore, a 164 lower population abundance the following year. Even though egg hatch occurring too early can also have 165 negative impacts on SBW populations, we assumed that this effect was negligible in the study area during 166 the 1986-2014 period (Régnière et al. 2012). Large-scale synchrony in white spruce cone production has been associated with weather conditions in the previous summer, during which cone primordia are initiated (Krebs et al. 2012). To 
verify this relationship, we quantified weather (precipitation and cumulative degree-days) during the

170 period of June to August of the preceding year for each $1 \times 1$ degree cell.

\section{Statistical analyses.}

173 characteristics of geographically disjunct populations" (Liebhold et al. 2012). The proportion of cells with

174 a higher moth abundance compared with the preceding year was used as an indicator of coincident change

175 in population abundance at this scale. Very high (1) or very low (0) proportions indicate synchrony at the 176 scale of the study area, with a proportion of 0.5 indicating no synchrony at this scale. It is noteworthy that 177 a proportion of 0.5 could mask synchronous population fluctuations across distances smaller than the size 178 of the study area. For example, a population increases in the eastern half of the territory coincident with a 179 population decrease in the western half could result in an overall proportion of 0.5 . However, finding an 180 explanation for synchrony across all spatial and temporal scales was impossible because one of the 181 explanatory variables (pollen cone abundance) was only available at the scale of the province. increases in each year was examined with general linear models (GLMs). The three weather variables mentioned above were used as predictors; for each variable, a province-level estimate for each year was obtained by calculating the median value of all cells. The white cone production index was also used as predictor. We compared several alternative statistical models to explain annual variation in the proportion

187 of cells, based on the Akaike Information Criterion for small sample sizes (AICc). Because the predicted variable is a proportion, the data were assumed to follow a binomial distribution. No autoregressive term 
192 (Hosmer et al. 2013). To examine whether the influence of the main explanatory variables was stationary 193 in time, we refitted the best model on a 10-year moving window subset along the 28-year dataset.

Alternative statistical models looking at the respective effects of precipitation and temperature of the preceding year on white spruce cone production were also formulated. In this case, we assumed that the response variable (cone production index) followed a Poisson distribution. The models were fitted with the glm function in R.

Finally, we examined how province-level population increases persist over time, and how they contributed to the rise of local SBW populations inside outbreak epicenters that appeared during the studied period. Epicenters were defined as the first locations where defoliation was detected from aerial surveys (Bouchard and Auger 2014). We used aerial defoliation surveys to delineate the epicenters and determine a date when outbreak population levels were reached in each of them, because these surveys provide a finer spatial information on SBW populations compared with pheromone traps. The epicenters were delineated by including a buffer zone surrounding the initial defoliation patches, to make sure that they were large enough to include at least 10 pheromone traps, for a reliable estimate of pre-outbreak population trends. Each epicenter was separated from the other ones by a distance $>50 \mathrm{~km}$. Six epicenters

207 were thus delineated (Fig. 1), with defoliation starting between 1991 and 2011. In each of these, SBW 208 populations were thus at different stages of outbreak development during any given year. Population 209 abundance in each epicenter was assessed by averaging moth abundance in all pheromone traps located 210 therein. In each epicenter, the occurrence of persistent population increases was determined with the 211 following method. A release was defined as a 5-fold increase in mean SBW abundance per trap for one 212 year compared with the preceding year. This criterion represented the upper range of population increases 213 observed throughout the study period, and it would be extremely unlikely that such increases are due to 214 measurement error. To make sure that this increase was significant from a long-term population dynamics 215 standpoint, we considered it to be 'persistent' if abundance during both of the next two years remained 
216 higher than during the year preceding the increase. Subsequently, we verified if these epicenter-level 217 persistent increases coincided with synchronous population increases at the province level.

\section{Results}

The proportion of cells with population increases was highly variable from year to year.

220 Population increases affecting more than $90 \%$ of the study area during a given year were observed in

221 1989, 1991 and 2006 (Figs. 2 and 3). Extensive population decreases were observed in 1987, 1990, 1993,

2222002 and 2007 (Figs. 2 and 3). During the remaining years, synchrony at the scale of the study area was

223 less pronounced, even if visual examination indicates that increases and decreases in population

224 abundance were often clustered at finer spatial scales (Fig. 3).

225 Comparison of the alternative statistical models indicates that the proportion of cells with an

226 increase in SBW populations during a given year was best explained by a model that included host tree

227 cone production and weather during early larval development (in May; Table 1). May temperature had

228 more impact on SBW population fluctuations than May precipitation, as shown by a higher z-value in the

229 best model (Table 2). Temperature during the flight period and date of hatching are included in the best

230 model for predicting large-scale population increases, but these variables do not appear to play a major

231 role, as indicated by their marginal effect on the AICc and pseudo $\mathrm{R}^{2}$ (Table 1 ). We further verified

232 whether the influence of environmental factors on SBW populations tended to vary during the 29-year

233 period by looking at GLM statistics in a 10-year moving window. This analysis suggested that the

234 influence of environmental variables was not stationary in time. Notably, the influence of host tree cone

235 production increased during the latter part of the 29-year series (Fig. 4c), and model fit improved

236 accordingly (Fig. 4a).

Host tree cone production was best explained by precipitation during the preceding year (Table

238 3). Integrating cumulative degree-days of the preceding year in the model did not improve model fit

239 (Table 3). 
Inside the six studied epicenters, several persistent population increases were detected, including

241 in 1989 (2 epicenters), 1991 (4), 1996 (1), 2006 (4) and 2011 (1) (Fig. 5). These persistent increases often

242 corresponded to province-level population increases (e.g. 1989, 1991, 2006 and 2011) and white spruce

243 mast years (e.g. 1996, 2006 and 2011). In all epicenters but one (Mauricie), province-level synchronous

244 SBW population increases closely coincided with the triggering of outbreaks, as assessed from defoliation 245 surveys (Fig. 5).

\section{Discussion}

\section{Effect of bottom-up factors on synchrony}

Even though detecting and describing synchrony in animal populations has become a relatively

249 straightforward process thanks to the availability of appropriate statistical techniques (Bjørnstad and

250 Falck 2001), explaining synchrony is still exceptionally challenging for several reasons. First, it is

251 difficult to sample at the same time population abundances and meaningful environmental drivers across

252 representative spatio-temporal scales. Second, when explanatory variables are available, they are usually

253 weather related, but the exact biological pathway through which weather affects population dynamics are 254 rarely identified. Third, there is a general lack of recognition for the fact that multiple causes are usually 255 involved, and that these causes might act at different scales.

The relatively simple approach developed in this study allowed us to establish a statistical

257 relationship between large-scale variations in SBW population abundance and two potential explanatory

258 variables, host tree cone production and weather during early larval development (in May). These

259 relationships provide a mechanistic explanation potentially connecting large-scale climatic variability

260 with insect population dynamics and synchrony. The first variable, host tree cone production, was related

261 to low precipitation during the previous summer (Table 3), which is known to synchronize the initiation

262 of reproductive buds and to favor high cone production in the following year (Krebs et al. 2012). In wind-

263 pollinated tree species, concentration of resources allocated to cone and seed production across large 
areas during some years is thought to be an adaptation that increases fitness (Kelly and Sork 2002). The

SBW feeds on pollen cones when they are available, particularly those of balsam fir (Blais 1952,

Greenbank 1963b, Bauce and Carisey 1996). This resource is likely to reduce the need for larvae to

267 disperse in search of food during early larval stages (Blais 1952). Dispersal-related mortality in $2^{\text {nd }}$ instar larvae emerging from diapause can be very important (up to 85\%) (Morris 1963, Régnière and Nealis 2008), and variation in mortality rates during this development stage may have major impacts on overall SBW population dynamics (Volney and Fleming 2007, Régnière and Nealis 2008).

SBW populations were also directly influenced by spring temperature during the current year. Warm, sunny and dry conditions are generally favorable to SBW larval development (Greenbank 1956, Pilon and Blais 1961). Spring conditions also influence the degree of mismatch between insect development just after the larvae emerge from overwintering, and the phenology of the current-year foliage on which the SBW feeds preferentially. In the case of the SBW, a better match is expected when conditions are warmer (Greenbank 1963a, Thomson et al. 1984). As with pollen cone abundance, a good phenological match with the young developing foliage is expected to reduce the risk of starvation (Trier and Mattson 1997) and dispersal-related mortality while foraging (Nealis and Lomic 1994, Lawrence et al. 1997). Because the population increases observed during some years in our study are very high (more than 5-fold in some cases; Figure 5), it is also possible that survival or dispersal during later development stages were also indirectly impacted by early spring conditions.

A true multi-scale perspective was not possible in this study, because the underlying environmental information, particularly the pollen cone index, were available only at the province level. It is likely that the relative influence of the various factors would have differed if they had been analysed at other scales. For example, one would expect that the effect of weather on moth flight activity, which was not significant in the province-level analyses (Table 1), may been significant if analysed across smaller areas. Indeed, because the SBW flight period, like many other phenological events in its annual life cycle, can vary by more than 1 month across the SBW's range in Québec (Régnière and Powell 2013), it is 
289

290

unlikely that male moth flight activity is affected by similar weather conditions at both ends of this gradient during any given year.

Different processes than those identified in our study could also explain large-scale synchronous population oscillations in some situations. Short-frequency oscillations in late epidemic, collapsing populations were also attributed to weather, but through an interaction with the natural enemies that build up when host population density increases, a top-down trophic process (Royama 1984, Régnière and Nealis 2007). Year-to-year variations in the emigration/migration (E/M) ratio also has been mentioned as a potential explanation (Régnière and Lysyk 1995, Royama et al. 2005). These other factors might explain why annual oscillations were relatively poorly predicted by the selected variables during the early portion of the time series (e.g. 1986-1995, Figure 4), which coincides with the collapse of the previous outbreak cycle (Morin et al. 2007). Natural enemies as well as the E/M ratio could thus represent alternative pathways through which weather could affect insect synchrony (Figure 6).

\section{Population synchrony and outbreak occurrence}

The same factors that synchronize population fluctuations at the province level also have the potential to generate local population increases that persist for several years, and sometimes coincide with outbreak initiation (Figure 5). Following outbreak initiation in an epicenter, the abundance of SBW populations can increase rapidly, particularly when balsam fir is abundant, such as was the case in the epicenters located in the eastern part of the province (Bouchard and Auger 2014). High population densities generate migration and exodus flights (Greenbank et al. 1980), explaining the contagious expansion patterns that are often observed in defoliation surveys (Bouchard and Auger 2014). Hence, while density-independent factors (weather, pollen cone production) play an important role for synchronization and potentially for outbreak triggering in low-density SBW populations, synchronization through density-dependant processes (migration flights, E/M ratio) probably becomes prevalent once outbreak conditions have been reached. A similar transition from bottom-up synchronizing agents acting 
through weather, to a dispersal related contagious expansion during the outbreak phase was also proposed

314 for geometrid moths (Jepsen et al. 2009).

In insect population dynamics, population cycles are often implied to be caused by delayed

316 density-dependent, top-down trophic processes (Royama 1992). For example, fluctuations due to

317 interactions with natural enemies have been emphasized for various insects such as bark beetles (Turchin

318 et al. 1999), geometrid moths (Hagen et al. 2010) or the larch budmoth (Turchin et al. 2003), as well as

319 for the SBW (Royama 1984). However, as recognized indirectly by these authors and as pointed out

320 directly by others (Baltensweiler and Fischlin 1988), the assumption that insect population cycles are

321 mainly driven by one or a few top-down processes can be oversimplifying. Our study suggests that the ca.

322 35-year outbreak cycle that was historically observed for the SBW (Morin et al. 2007) is more likely to be

323 explained by a complex mix of factors including top-down, bottom-up and dispersal-related processes,

324 and that the relative influence of these factors is highly heterogeneous in space and time.

\section{Synchrony and climate change}

A mechanistic understanding of forest ecosystem disturbance processes, including of their

327 complex relationships with climatic factors or forest characteristics, is needed to obtain realistic

328 predictions about their future impacts (Williams and Jackson 2007). Our study shows that there are

329 several functional pathways through which climate and weather can influence insect population

330 dynamics. In the case of the SBW, length of the growing season has already been identified as an

331 important constraint on the northern and southern boundaries of potential outbreak occurrence (Régnière

332 et al. 2012). The current study shows that annual variation in weather conditions can also explain spatial

333 synchrony within this distribution, both directly (through their effect on larval development in early

334 spring) and indirectly (through their connection with host tree cone production). Furthermore, the

335 regional-level abundance of pollen cones available for insect consumption does not only change on an

336 annual basis, but also, on a longer time frame, as a function of variation in the abundance of populations 
337 of host tree species, and in the age structure of these populations (Blais 1983). These complex interactions

338 indicate that predicting insect population dynamics and potential outbreak occurrence represents a

339 considerable challenge in the context of a changing climate and pervasive habitat modifications.

340 Acknowledgements. Thanks to Vince Nealis and Emma Despland for providing useful comments on

341 earlier drafts. We also thank Guy Rhéaume (MFFP) for compiling the pheromone trap data, as well as

342 Sylvie Carles (MFFP) for providing the seed collection data. We also thank the anonymous reviewers for 343 their constructive comments. 


\section{References}

Baltensweiler, W., and A. Fischlin. 1988. The larch budmoth in the Alps. Pages 331-351 Dynamics of forest insect populations. Springer.

Bauce, É., and N. Carisey. 1996. Larval feeding behaviour affects the impact of staminate flower production on the suitability of balsam fir trees for spruce budworm. Oecologia 105:126-131.

Bjørnstad, O. N., and W. Falck. 2001. Nonparametric spatial covariance functions: estimation and testing. Environmental and Ecological Statistics 8:53-70.

Blais, J. R. 1952. The relationship of the spruce budworm (Choristoneura fumiferana, Clem.) to the flowering condition of balsam fir (Abies balsamea (L.) Mill.). Canadian Journal of Zoology 30:129.

Blais, J. R. 1983. Trends in the frequency, extent, and severity of spruce budworm outbreaks in eastern Canada. Canadian Journal of Forest Research 13:539-547.

Bouchard, M., and I. Auger. 2014. Influence of environmental factors and spatio-temporal covariates during the initial development of a spruce budworm outbreak. Landscape ecology 29:111-126.

Bouchard, M., D. Kneeshaw, and Y. Bergeron. 2006. Forest dynamics after successive spruce budworm outbreaks in mixedwood forests. Ecology 87:2319-2329.

Briggs, C. J., and M. F. Hoopes. 2004. Stabilizing effects in spatial parasitoid-host and predator-prey models: a review. Theoretical population biology 65:299-315.

Carisey, N., and E. Bauce. 1997. Impact of balsam fir flowering on pollen and foliage biochemistry in relation to spruce budworm growth, development and food utilization. Entomologia Experimentalis et Applicata 85:17-31.

Greenbank, D. O. 1956. The role of climate and dispersal in the initiation of outbreaks of the spruce budworm in New Brunswick: I. The role of climate. Canadian Journal of Zoology 34:453-476.

Greenbank, D. O. 1963a. Host species and the spruce budworm. Memoirs of the Entomological Society of Canada 95:219-223.

Greenbank, D. O. 1963b. Staminate flowers and the spruce budworm. Memoirs of the Entomological Society of Canada 95:202-218.

Greenbank, D. O., G. W. Schaefer, and R. C. Rainey. 1980. Spruce budworm (Lepidoptera: Tortricidae) moth flight and dispersal: new understanding from canopy observations, radar, and aircraft. Memoirs of the Entomological Society of Canada 112:1-49.

Hagen, S. B., J. U. Jepsen, T. Schott, and R. A. Ims. 2010. Spatially mismatched trophic dynamics: cyclically outbreaking geometrids and their larval parasitoids. Biology Letters 6:566-569.

Haynes, K. J., O. N. Bjørnstad, A. J. Allstadt, and A. M. Liebhold. 2013. Geographical variation in the spatial synchrony of a forest-defoliating insect: isolation of environmental and spatial drivers. Proceedings of the Royal Society of London B: Biological Sciences 280:20122373.

Hosmer, D. W., S. Lemeshow, and R. X. Sturdivant. 2013. Applied Logistic Regression. John Wiley \& Sons, New-York, NY.

Houle, G. 1999. Mast seeding in Abies balsamea, Acer saccharum and Betula alleghaniensis in an old growth, cold temperate forest of north-eastern North America. Journal of Ecology 87:413-422.

Jepsen, J. U., S. B. Hagen, S.-R. Karlsen, and R. A. Ims. 2009. Phase-dependent outbreak dynamics of geometrid moth linked to host plant phenology. Proceedings of the Royal Society of London B: Biological Sciences:rspb20091148.

Kelly, D., and V. L. Sork. 2002. Mast seeding in perennial plants: why, how, where? Annual Review of Ecology and Systematics 33:427-447.

Koenig, W. D. 2002. Global patterns of environmental synchrony and the Moran effect. Ecography 25:283-288. 
Krebs, C. J., J. M. LaMontagne, A. J. Kenney, and S. Boutin. 2012. Climatic determinants of white spruce cone crops in the boreal forest of southwestern Yukon. Botany 90:113-119.

Lawrence, R. K., W. J. Mattson, and R. A. Haack. 1997. White spruce and the spruce budworm: defining the phenological window of susceptibility. The Canadian Entomologist 129:291-318.

Liebhold, A. M., K. J. Haynes, and O. N. Bjørnstad. 2012. Spatial synchrony of insect outbreaks. Pages 113-125 in P. Barbosa, D. K. Letourneaum, and A. A. Agrawal, editors. Insect outbreaks revisited. John Wiley \& Sons, Chichester, UK.

Moran, P. 1953. The statistical analysis of the Canadian lynx cycle. Australian Journal of Zoology 1:291298.

Moreira, X., L. Abdala-Roberts, Y. B. Linhart, and K. A. Mooney. 2014. Masting promotes individual-and population-level reproduction by increasing pollination efficiency. Ecology 95:801-807.

Morin, H., Y. Jardon, and R. Gagnon. 2007. Relationship between spruce budworm outbreaks and forest dynamics in eastern North America. Pages 555-577 in E. A. Johnson and K. Miyanishi, editors. Plant Disturbance Ecology-The Process and the Response. Elsevier, Amsterdam, The Netherlands.

Morris, R. F. 1963. The dynamics of epidemic spruce budworm populations. Memoirs of the Entomological Society of Canada 95:1-12.

Myers, J. H., and J. S. Cory. 2013. Population cycles in forest Lepidoptera revisited. Annual Review of Ecology, Evolution, and Systematics 44:565-592.

Nealis, V., and P. Lomic. 1994. Host-plant influence on the population ecology of the jack pine budworm, Choristoneura pinus (Lepidoptera: Tortricidae). Ecological Entomology 19:367-373.

Nealis , V. G. 2003. Host-plant relationships and comparative ecology of conifer-feeding budworms. Pages 66-74 in M. L. McManus and A. M. Liebhold, editors. Proceedings of Ecology, Survey and Management of Forest Insects, Kraków, Poland, 1 - 5 September 2002. GTR NE-311. USDA Forest Service, Newtown Square, PA

Pilon, J. G., and J. R. Blais. 1961. Weather and outbreaks of the spruce budworm in the province of Quebec from 1939 to 1956. The Canadian Entomologist 93:118-123.

Régnière, J. 1984. Vertical transmission of diseases and population dynamics of insects with discrete generations: a model. Journal of Theoretical Biology 107:287-301.

Régnière, J., J. Delisle, D. S. Pureswaran, and R. Trudel. 2013a. Mate-finding allee effect in spruce budworm population dynamics. Entomologia Experimentalis et Applicata 146:112-122.

Régnière, J., and T. J. Lysyk. 1995. Population dynamics of the spruce budworm, Choristoneura fumiferana. Pages 95-105 in J. A. Armstrong and W. G. H. Ives, editors. Forest Insect Pests in Canada. Canadian Forest Service, Ottawa, Canada.

Régnière, J., and V. Nealis. 2007. Ecological mechanisms of population change during outbreaks of the spruce budworm. Ecological Entomology 32:461-477.

Régnière, J., and V. G. Nealis. 2008. The fine-scale population dynamics of spruce budworm: survival of early instars related to forest condition. Ecological Entomology 33:362-373.

Régnière, J., and J. A. Powell. 2013. Animal life cycle models (Poikilotherms). Pages 295-316 in M. Schwartz, editor. Phenology: An Integrative Environmental Science. Springer, Dordrecht.

Régnière, J., R. St-Amant, and A. Béchard. 2013b. BioSIM 10-User's Manual. Canadian Forest Service, Québec, Canada.

Régnière, J., R. St-Amant, and P. Duval. 2012. Predicting insect distributions under climate change from physiological responses: spruce budworm as an example. Biological Invasions 14:1571-1586.

Rhainds, M., P. Therrien, and L. Morneau. 2016. Pheromone-Based Monitoring of Spruce Budworm (Lepidoptera: Tortricidae) Larvae in Relation to Trap Position. Journal of economic entomology 109:717-723. 
Robert, E., S. Brais, B. D. Harvey, and D. Greene. 2012. Seedling establishment and survival on decaying logs in boreal mixedwood stands following a mast year. Canadian Journal of Forest Research 42:1446-1455.

Rose, A. H., and J. R. Blais. 1954. A relation between April and May temperatures and spruce budworm larval emergence. The Canadian Entomologist 86:174-177.

Rossi, S., H. Morin, F. Gionest, and D. Laprise. 2012. Episodic recruitment of the seedling banks in balsam fir and white spruce. American journal of botany 99:1942-1950.

Royama, T. 1984. Population dynamics of the spruce budworm Choristoneura fumiferana. Ecological Monographs 54:429-462.

Royama, T. 1992. Analytical population dynamics. Chapman and Hall. London, United Kingdom.

Royama, T., W. MacKinnon, E. Kettela, N. Carter, and L. Hartling. 2005. Analysis of spruce budworm outbreak cycles in New Brunswick, Canada, since 1952. Ecology 86:1212-1224.

Sanders, C. J. 1996. Pheromone traps for detecting incipient outbreaks of the spruce budworm, Choristoneura fumiferana (Clem.) NODA/NFP Technical Report TR-32.

Sanders, C. J., D. R. Wallace, and G. S. Lucuik. 1978. Flight activity of female eastern spruce budworm (Lepidoptera: Tortricidae) at constant temperatures in the laboratory. The Canadian Entomologist 110:627-632.

Team, R. D. C. 2013. R: A Language and Environment for Statistical Computing. R Foundation For Statistical Computing, Vienna, Austria.

Thomson, A., R. Shepherd, J. Harris, and R. Silversides. 1984. Relating weather to outbreaks of western spruce budworm, Choristoneura occidentalis (Lepidoptera: Tortricidae), in British Columbia. The Canadian Entomologist 116:375-381.

Trier, T. M., and W. J. Mattson. 1997. Needle mining by the spruce budworm provides sustenance in the midst of privation. Oikos 79:241-246.

Turchin, P., A. Taylor, and J. Reeve. 1999. Dynamical role of predators in population cycles of a forest insect: an experimental test. Science 285:1068-1071.

Turchin, P., S. N. Wood, S. P. Ellner, B. E. Kendall, W. W. Murdoch, A. Fischlin, J. Casas, E. McCauley, and C. J. Briggs. 2003. Dynamical effects of plant quality and parasitism on population cycles of larch budmoth. Ecology 84:1207-1214.

Volney, W. J. A., and R. A. Fleming. 2007. Spruce budworm (Choristoneura spp.) biotype reactions to forest and climate characteristics. Global Change Biology 13:1630-1643.

Williams, D. W., and A. M. Liebhold. 2000. Spatial synchrony of spruce budworm outbreaks in eastern North America. Ecology 81:2753-2766.

Williams, J. W., and S. T. Jackson. 2007. Novel climates, no-analog communities, and ecological surprises. Frontiers in Ecology and the Environment 5:475-482. 
475 Table 1 - Relative support for candidate models describing the effect of environmental variables on 476 synchrony, measured as the proportion of cells with increases in SBW abundance.

\begin{tabular}{lrrrr} 
Model & K & AICc & $\Delta$ AICc & Pseudo-R \\
\hline MayW + Cones + Flight + Hatch & 6 & 416.07 & 0.00 & 0.42 \\
MayW + Cones + Flight & 5 & 418.11 & 2.04 & 0.41 \\
MayW + Cones & 4 & 430.86 & 14.79 & 0.38 \\
MayW + Cones + Hatch & 5 & 431.34 & 15.27 & 0.38 \\
MayW & 3 & 516.90 & 100.83 & 0.20 \\
Cones & 2 & 541.95 & 125.88 & 0.15 \\
Hatch & 2 & 602.41 & 186.34 & 0.04 \\
Flight & 2 & 610.30 & 194.23 & 0.02
\end{tabular}

478 Note: "MayW" includes precipitation and cumulative degree-days during the month of May, "Flight" 479 corresponds to mean maximal daily temperature during the adult flight period, and "Hatch" to the date at 480 which egg hatch peaked during the preceding year (late summer). 
482 Table 2 - Summary statistics of the best model (c.f. Table 1) analyzing the effects of environmental 483 variables on SBW population synchrony, measured as the proportion of cells with population increases.

484

\begin{tabular}{lrrrr} 
Variable & Estimate & Std. Error & $\mathrm{z}$ value & $\operatorname{Pr}(>|\mathrm{z}|)$ \\
\hline (Intercept) & -3.07 & 2.02 & -1.52 & 0.1296 \\
May degree-days & 0.02 & 0.00 & 10.41 & $<0.0001$ \\
May precipitation & 0.02 & 0.00 & 6.71 & $<0.0001$ \\
Cones & 0.46 & 0.06 & 7.76 & $<0.0001$ \\
Flight & 5.80 & 1.36 & 4.25 & $<0.0001$ \\
Hatch & -0.02 & 0.01 & -2.30 & 0.0215
\end{tabular}

485

486

487

488 
489 Table 3 - Relative support for candidate models describing the effect of weather of the preceding (y-1) 490 year on the white spruce cone production index.

\begin{tabular}{llrrr} 
Model & $\mathrm{K}$ & AICc & $\Delta$ AICc & Pseudo- $^{2}$ \\
\hline Precipitation $^{\mathrm{y}-1}$ & $\mathbf{2}$ & $\mathbf{7 5 . 0 4}$ & $\mathbf{0}$ & $\mathbf{0 . 3 5 3}$ \\
Degree-days $^{\mathrm{y}-1}+$ Precipitation $^{\mathrm{y}-1}$ & 3 & 77.41 & 2.37 & 0.357 \\
Degree-days $^{\mathrm{y}-1}$ & 2 & 82.70 & 7.66 & 0.124
\end{tabular}

491

492

493

494 

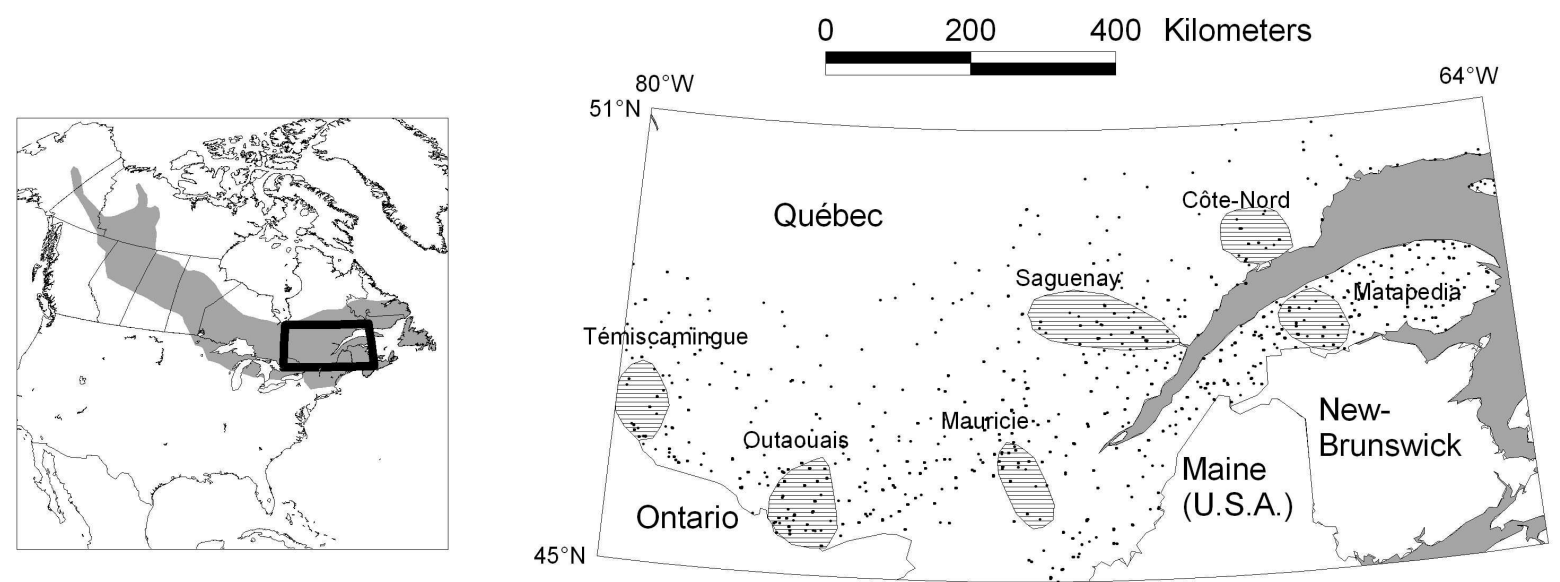

497 Figure 1. Location of the sample plots where pheromone traps were placed (red dots). The shaded area in the left inset indicates the distribution of the SBW across North-America. Cross-hatching in the right inset indicates the location of different outbreak epicenters that appeared observed during the 1986-2014

500 period.

501 


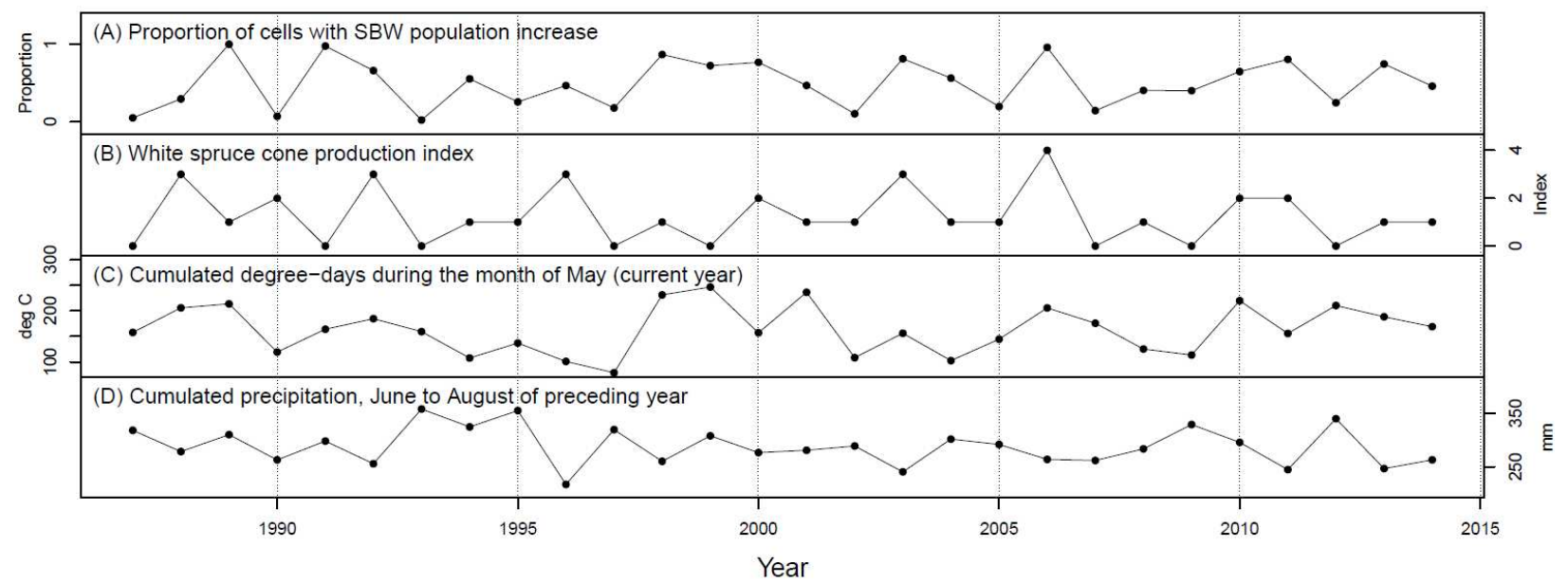

Figure 2. Year to year variations in the degree of synchrony (A) and environmental variables (B-D). Variables (B) and (C) are significant predictors of proportion of cells with population increase (A) (c.f. Table 1), and cumulated precipitation of preceding year (D) is a significant predictor of white spruce cone production index (B) (c.f. Table 3). 

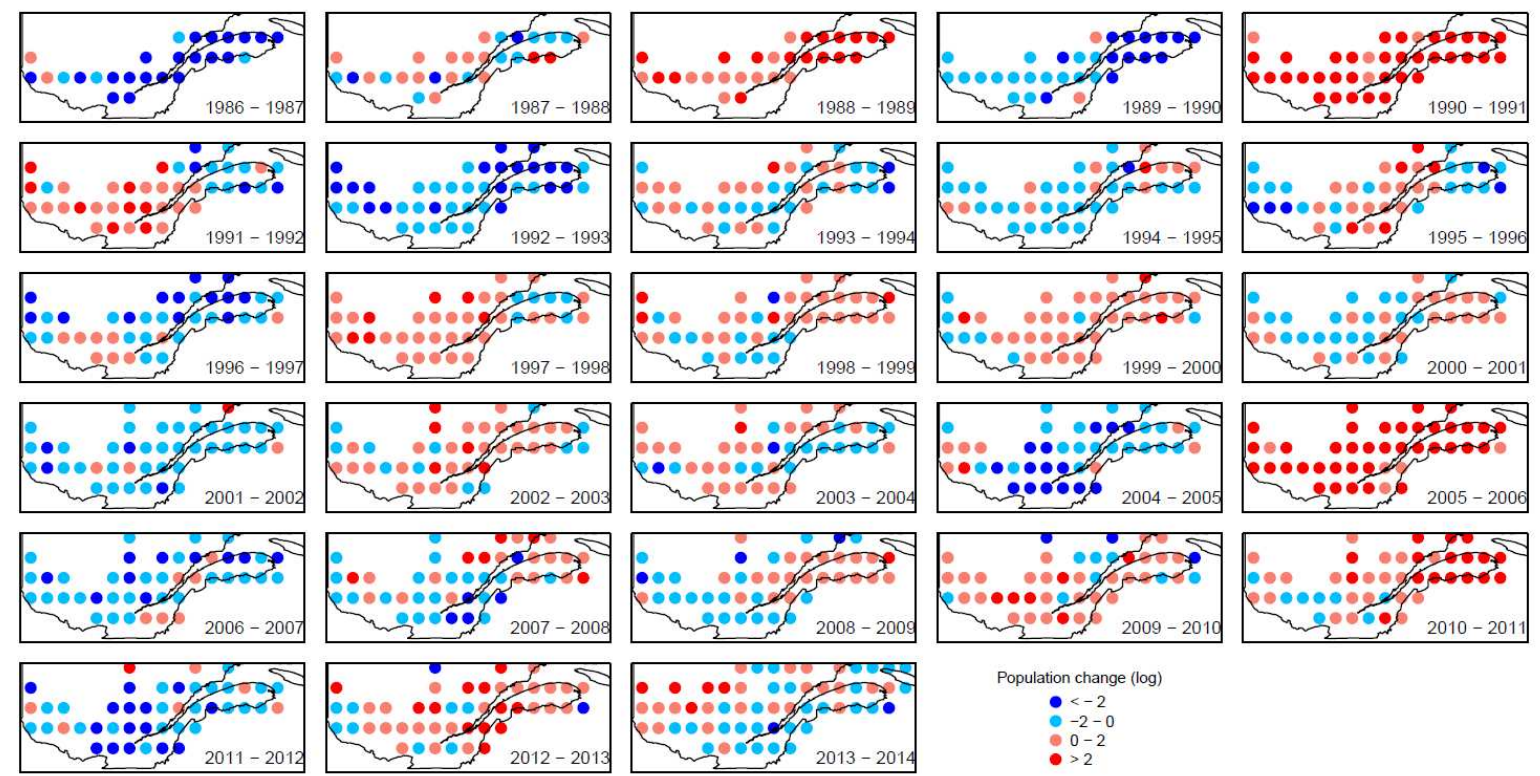

Population change (log)

$\bullet<-2$
$-2-0$

$0-2-0$
0

511 Figure 3. Annual changes in SBW population abundance. Each dot represents the difference between

512 years $y$ and $y-1$ in the averaged number of moths $(\log 10[\mathrm{x}+1])$ for a cell of $1 \mathrm{deg} \mathrm{x} 1 \mathrm{deg}$. 
514
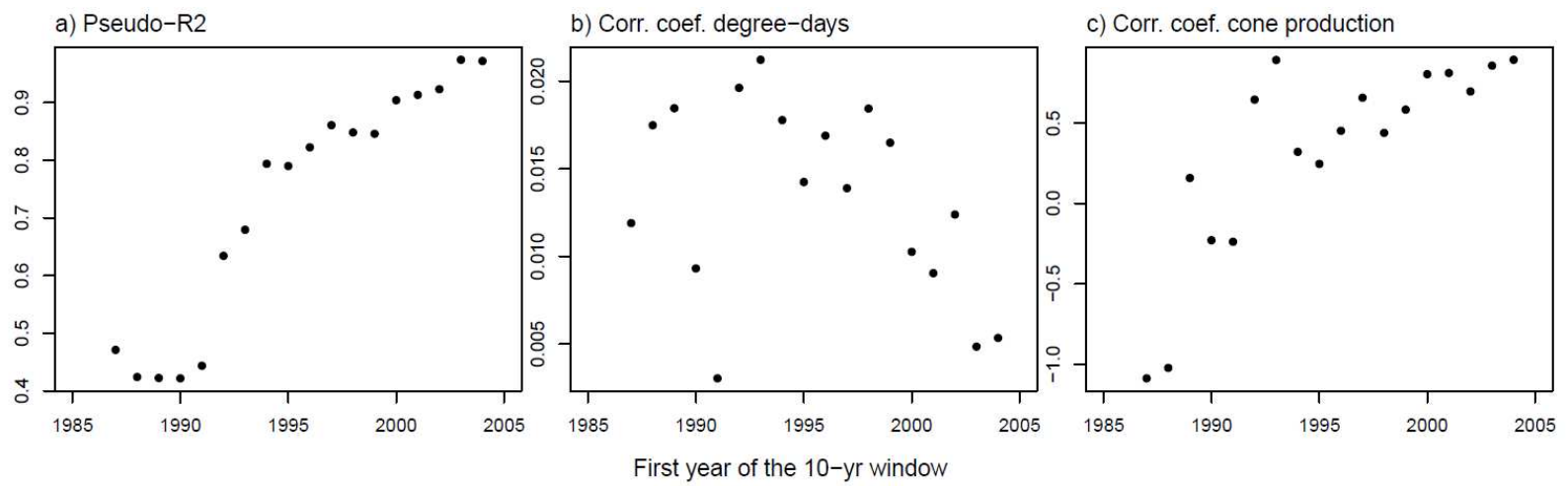

Figure 4. Temporal variation in statistics for the best model (Table 1) predicting changes in SBW

517 abundance at the province level. Separate models were fitted for each successive 10-year time window. 


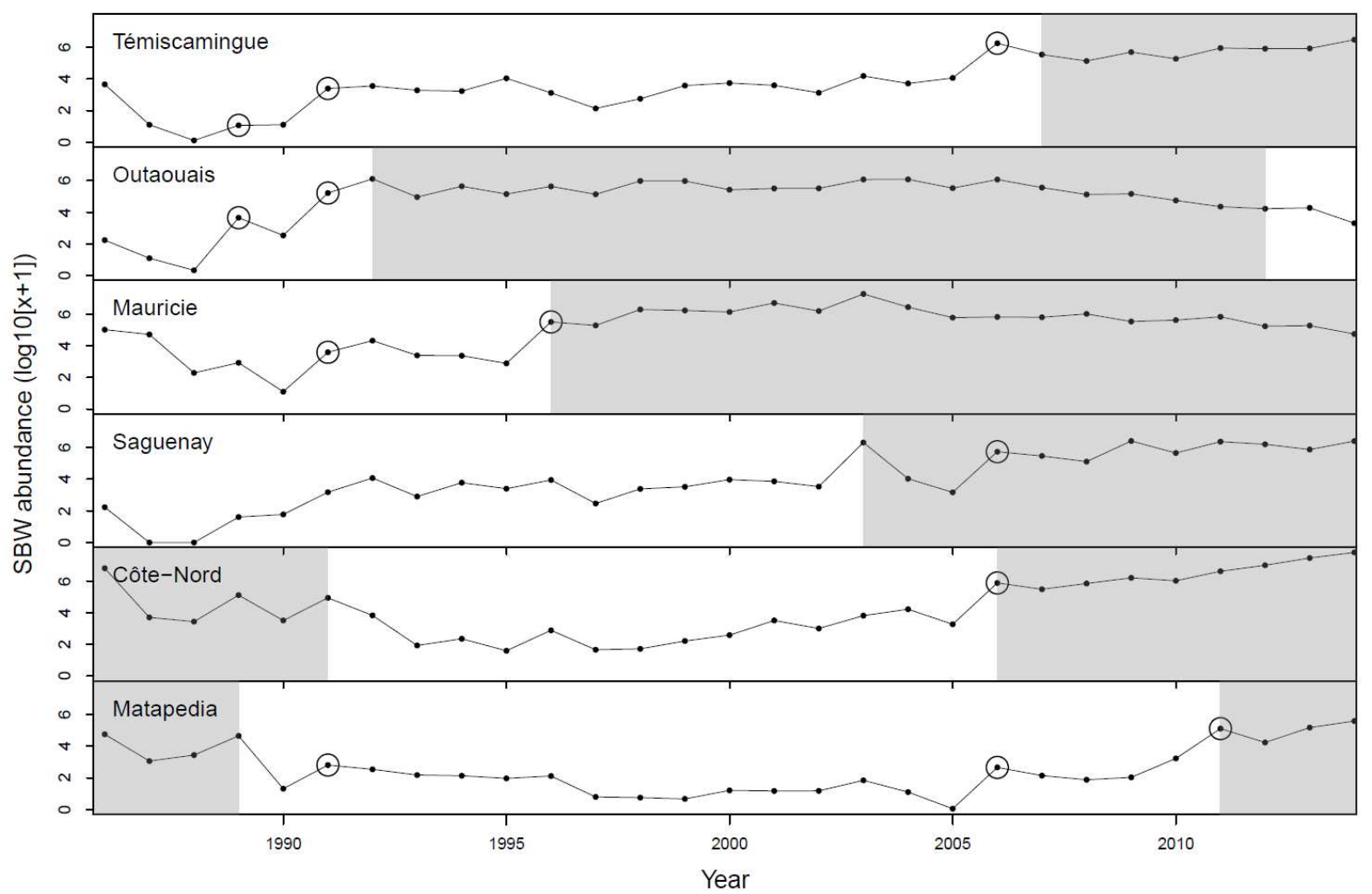

Figure 5. SBW population levels in six epicenters (c.f. Figure 1) where SBW outbreaks were detected during the 1986-2014 period. The shaded areas indicate the period during which defoliation could be detected from aerial surveys, corresponding to outbreak conditions. Larger circles indicate the beginning of a "persistent" population increase, defined as a $5 \mathrm{x}$ annual increase, with subsequent populations that remained above the pre-increase level for at least two years. Persistent increases were calculated from untransformed abundances, but log-transformed values are represented in the figure. 


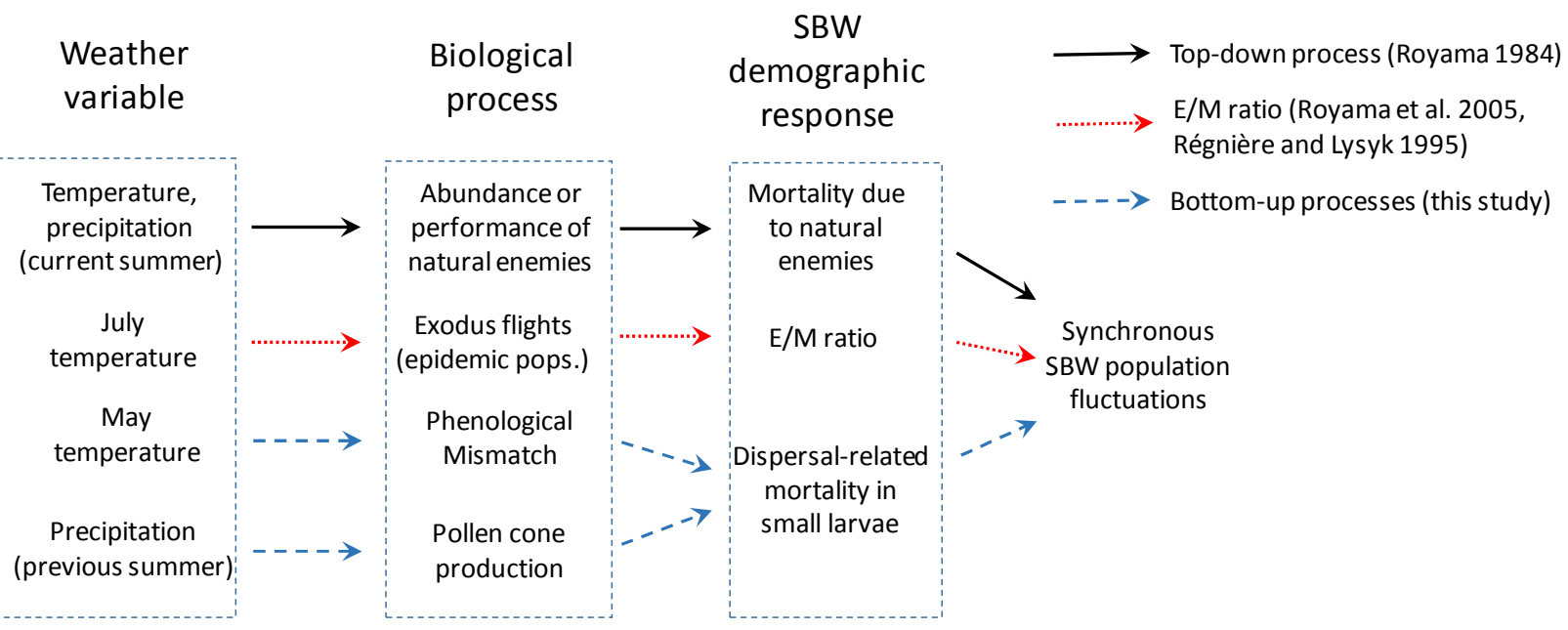

530 Figure 6. Hypothetical biological pathways through which interannual variation in different weather variables could produce large-scale synchronized SBW population fluctuations. 
Supplementary material 1

Mean number of spruce budworms per trap in each 1 deg x 1 deg cell for each year.

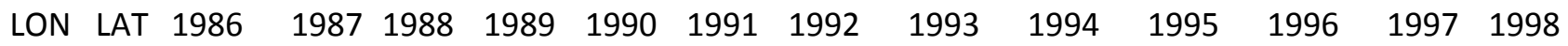

$\begin{array}{llllllllll}-80 & 48 & 1173 & 86.0 & 38.7 & 31.7 & 45.3 & 20.7 & 2.7 & 11.7\end{array}$

$\begin{array}{lllllllllllllll}-79 & 47 & 28.4 & 1.5 & 0.2 & 2.6 & 1.5 & 27.5 & 36.3 & 25.5 & 24.1 & 55.5 & 21.5 & 7.4 & 14.5\end{array}$

$\begin{array}{lllllllllllllll}-79 & 48 & 0.0 & 0.0 & 0.0 & 11.7 & 4.0 & 21.7 & 120.5 & 37.7 & 60.0 & 45.0 & 41.3 & 11.7 & 15.3\end{array}$

$\begin{array}{llllllllllll}-79 & 49 & 51.5 & 73.3 & 436.5 & 42.7 & 37.7 & 36.0 & 30.3 & 3.0 & 9.3\end{array}$

$\begin{array}{lllllllllllllll}-78 & 46 & 3.0 & 0.0 & 0.0 & 7.0 & 0.0 & 63.4 & 58.3 & 25.8 & 27.6 & 36.6 & 34.4 & 12.9 & 24.7\end{array}$

$\begin{array}{lllllllllllllll}-78 & 47 & 2.0 & 2.3 & 0.0 & 3.7 & 1.0 & 15.2 & 31.6 & 22.8 & 27.7 & 59.5 & 19.8 & 8.5 & 25.3\end{array}$

$\begin{array}{lllllllllll}-78 & 48 & 59.3 & 59.0 & 18.3 & 22.3 & 21.3 & 13.3 & 4.3 & 11.7\end{array}$

$\begin{array}{lllllllllllllll}-77 & 46 & 9.8 & 1.4 & 0.6 & 38.8 & 20.6 & 205.0 & 397.5 & 190.4 & 278.7 & 220.1 & 85.4 & 93.8 & 242.5\end{array}$

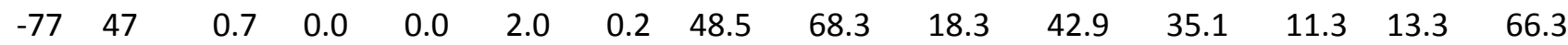

$\begin{array}{llllllllllll}-77 & 48 & 5.3 & 50.5 & 113.3 & 35.8 & 43.8 & 36.0 & 20.3 & 5.8 & 26.3\end{array}$

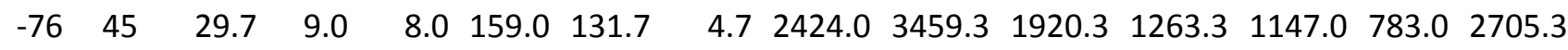

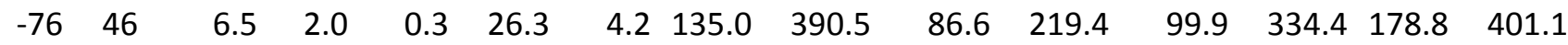

$\begin{array}{lllllllllllllll}-76 & 47 & 3.1 & 0.2 & 0.1 & 1.5 & 0.6 & 46.0 & 166.2 & 35.0 & 32.1 & 25.3 & 25.4 & 26.8 & 65.0\end{array}$

$\begin{array}{lllllllllllllll}-75 & 46 & 1.6 & 0.1 & 0.0 & 4.7 & 0.4 & 45.5 & 98.9 & 38.7 & 48.2 & 23.2 & 35.0 & 52.7 & 72.1\end{array}$

$\begin{array}{lllllllllllllll}-75 & 47 & 0.5 & 0.0 & 0.0 & 1.9 & 0.8 & 37.9 & 52.6 & 32.4 & 33.1 & 29.1 & 21.4 & 19.8 & 37.1\end{array}$

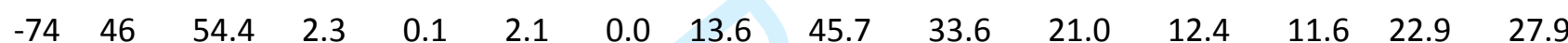

$\begin{array}{lllllllllllllll}-74 & 47 & 28.0 & 0.0 & 0.0 & 0.8 & 0.0 & 6.2 & 13.2 & 10.4 & 7.9 & 9.5 & 6.9 & 8.9 & 18.9\end{array}$

$\begin{array}{llllllllllllll}-74 & 48 & 0.0 & 0.0 & 4.0 & 1.0 & 6.2 & 14.8 & 6.0 & 10.0 & 13.0 & 12.5 & 5.8 & 7.0\end{array}$

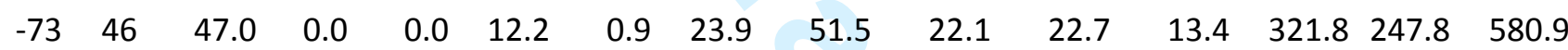

$\begin{array}{lllllllllllllll}-73 & 47 & 284.7 & 60.8 & 4.4 & 4.7 & 0.4 & 14.9 & 42.7 & 12.5 & 14.1 & 9.9 & 22.5 & 19.8 & 72.6\end{array}$

$\begin{array}{lllllllllll}-73 & 48 & 0.3 & 4.2 & 24.8 & 15.4 & 27.2 & 16.2 & 27.3 & 7.0 & 12.5\end{array}$

$-73 \quad 49$

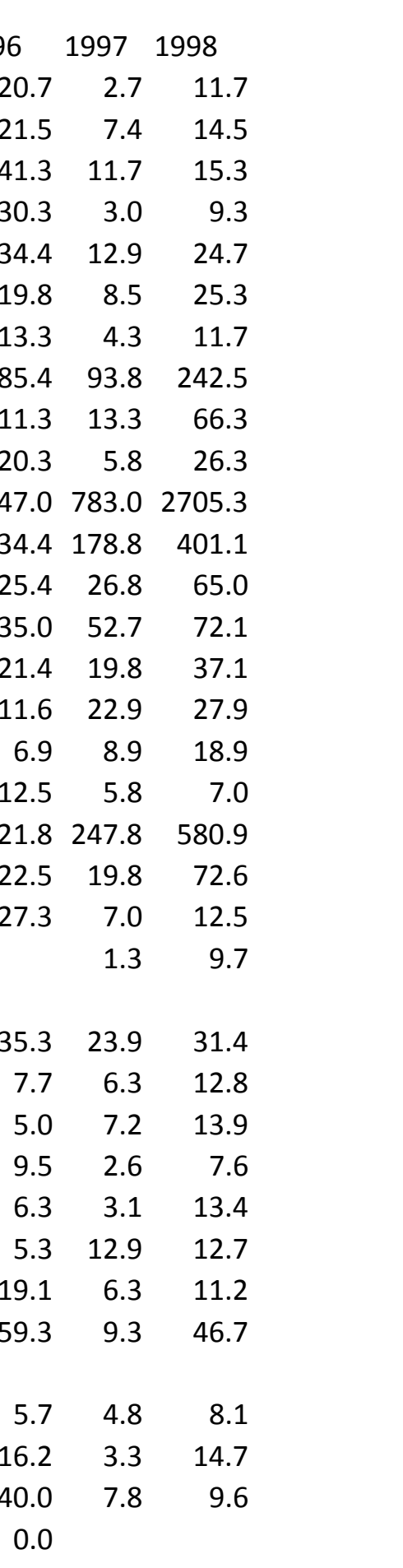

$-73 \quad 50$

$\begin{array}{ll}-72 & 45\end{array}$

$-7246$

$\begin{array}{ll}-72 & 47\end{array}$

$\begin{array}{ll}-72 & 48\end{array}$

$-71 \quad 46$

$\begin{array}{ll}-71 & 47\end{array}$

$\begin{array}{ll}-71 & 48\end{array}$

$-71 \quad 49$

$-70 \quad 46$

$\begin{array}{ll}-70 & 47\end{array}$

$\begin{array}{lllllll}52.7 & 0.0 & 0.0 & 1.7 & 0.0 & 15.7 & 18.9\end{array}$

$\begin{array}{rrrr}5.3 & 0.3 & 27.8 & 58.3 \\ & 0.0 & 5.2 & 17.6\end{array}$

15.3

38.1

22.8

$\begin{array}{lll}0.0 & 5.2 & 17.6\end{array}$

$8.7 \quad 22.5$

7.2

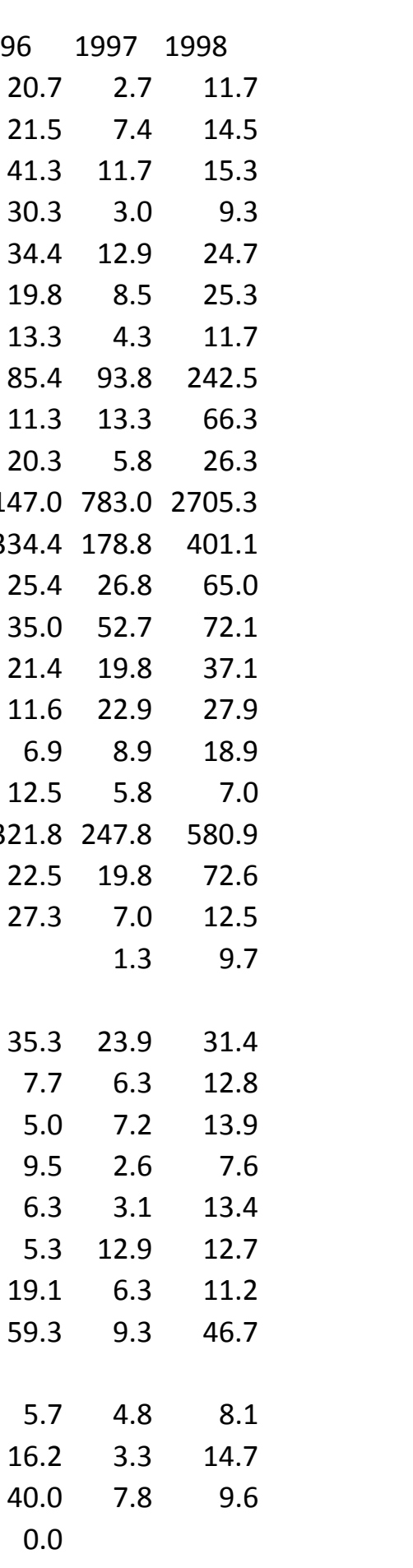

$\begin{array}{lllllll}20.3 & 0.0 & 0.0 & 1.5 & 0.1 & 2.8 & 14\end{array}$

$\begin{array}{lll}17.0 & 0.0 & 0.0\end{array}$

$\begin{array}{lll}4.0 & 0.2 & 1.8\end{array}$

5.3

$9.9 \quad 7.5$

3.4

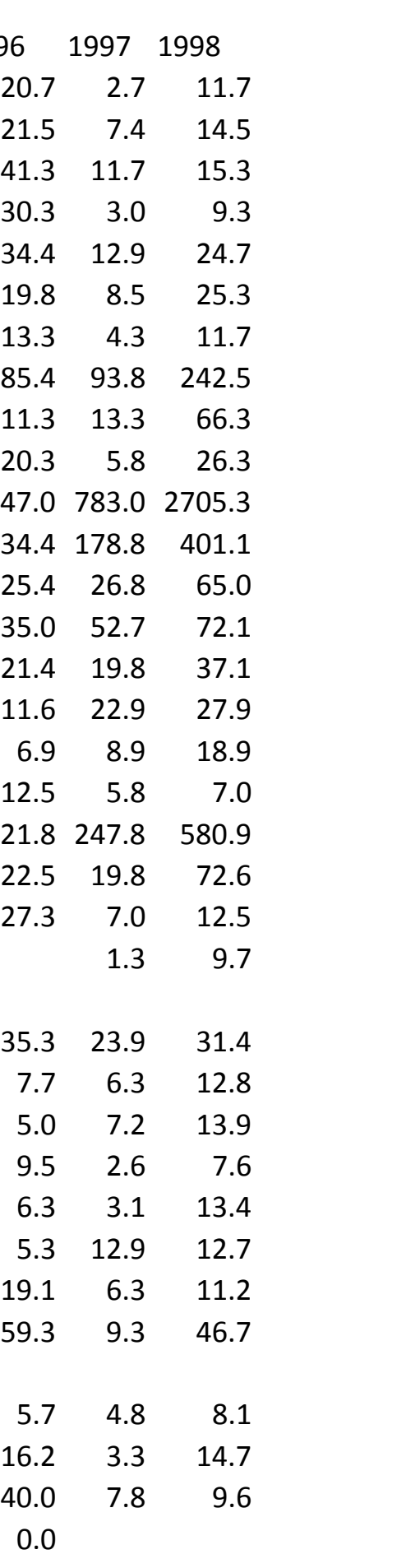

$\begin{array}{ll}-70 & 48\end{array}$

$\begin{array}{llllll}6.7 & 0.6 & 0.1 & 1.6 & 0.0 & 3.7\end{array}$

$2.3 \quad 11.2$

6.8

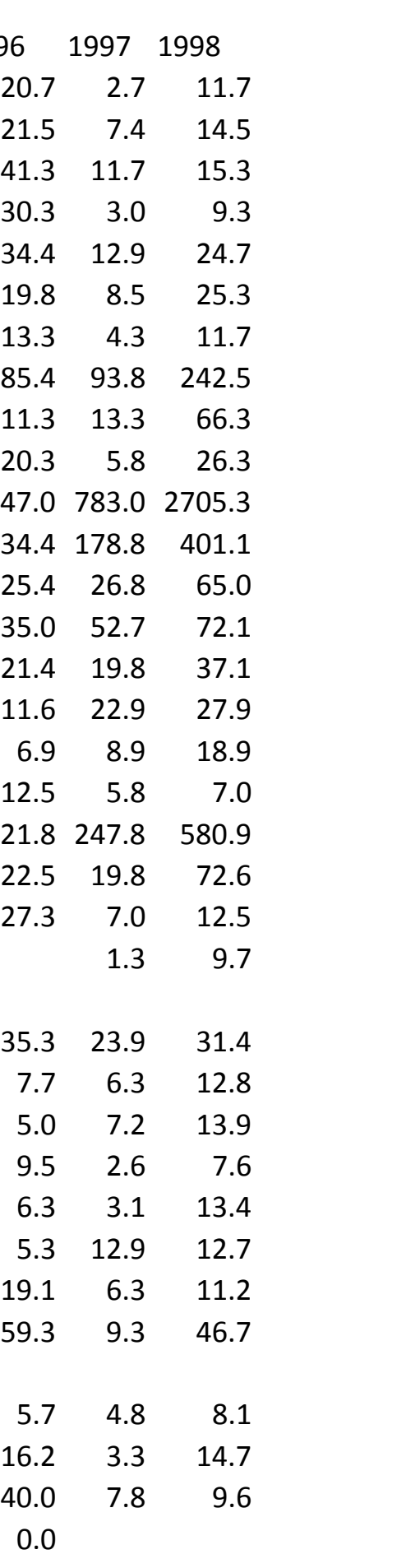

$\begin{array}{ll}-70 \quad 49 \\ -69 & 47\end{array}$

$\begin{array}{lll}8.3 & 0.0 & 0.0\end{array}$

0.0

4.0

$\begin{array}{lll}2.9 & 12.2 & 29.2\end{array}$

3.9

3.1

1.6

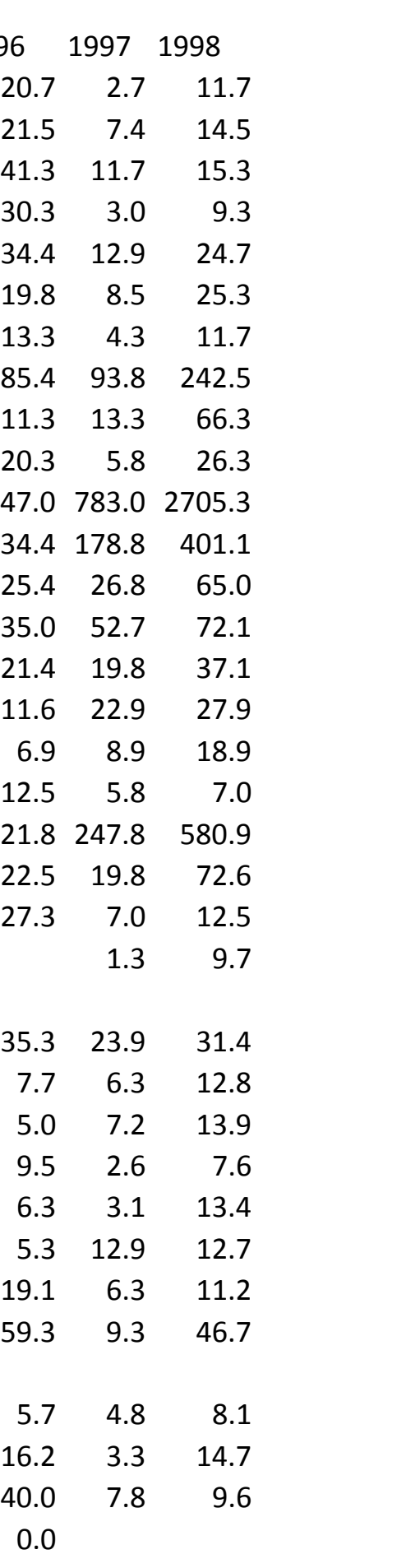

$\begin{array}{ll}-69 & 47\end{array}$

$0.3 \quad 0.0$

1.3

6.326 .2

26.2

12.7

$5.4 \quad 3.7$

2.7

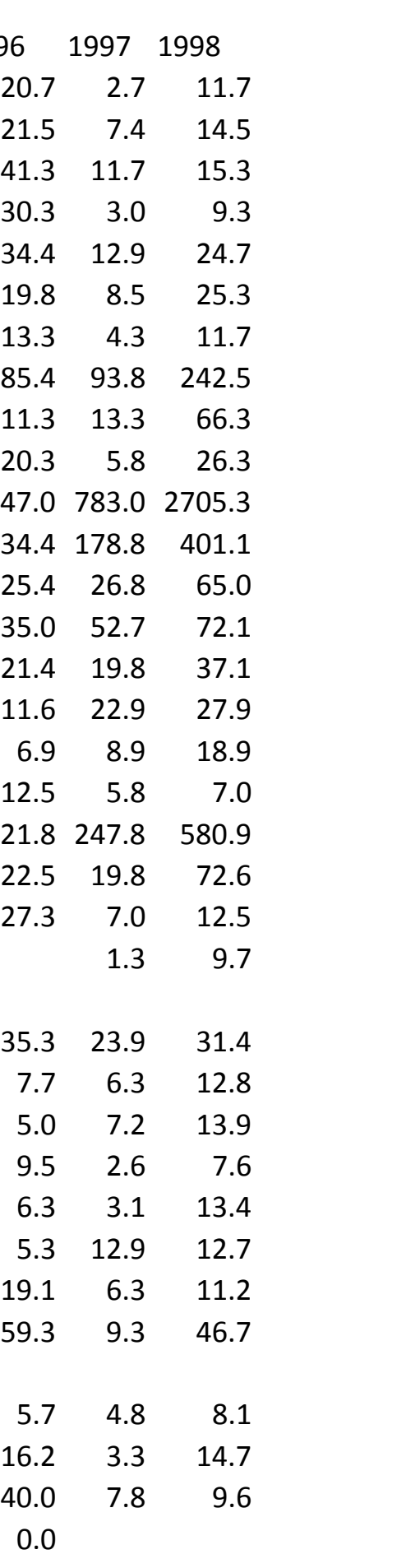

$\begin{array}{ll}-69 & 48\end{array}$ 23.7

8.0

$9.2 \quad 14.0$

13.3

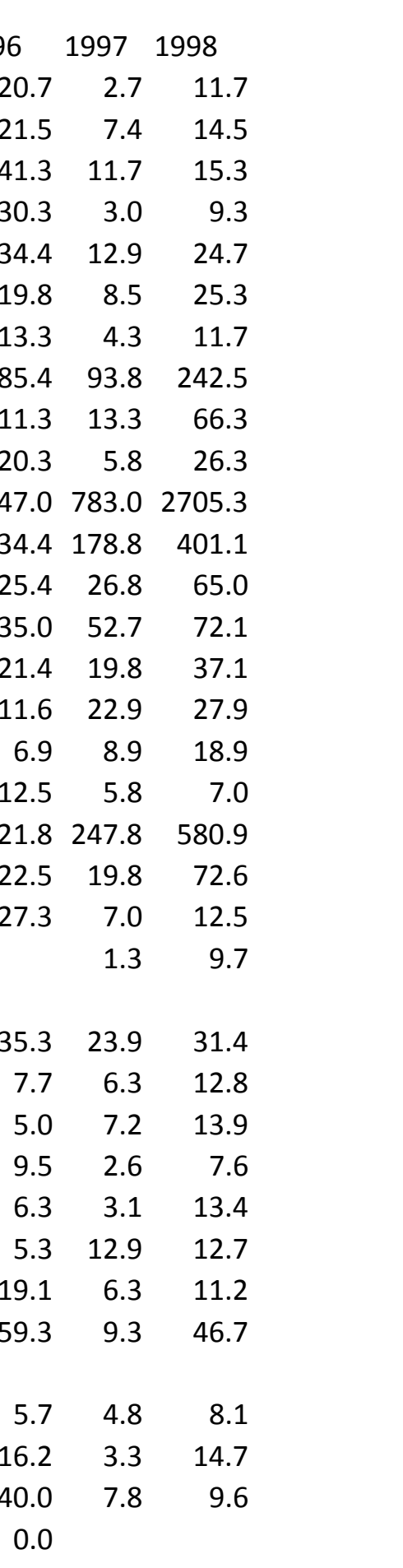

$\begin{array}{ll}-69 & 49\end{array}$

$25.9-0.3$

$\begin{array}{ll}0.0 & 3.0\end{array}$

20.7

26.7

74.7

35.3

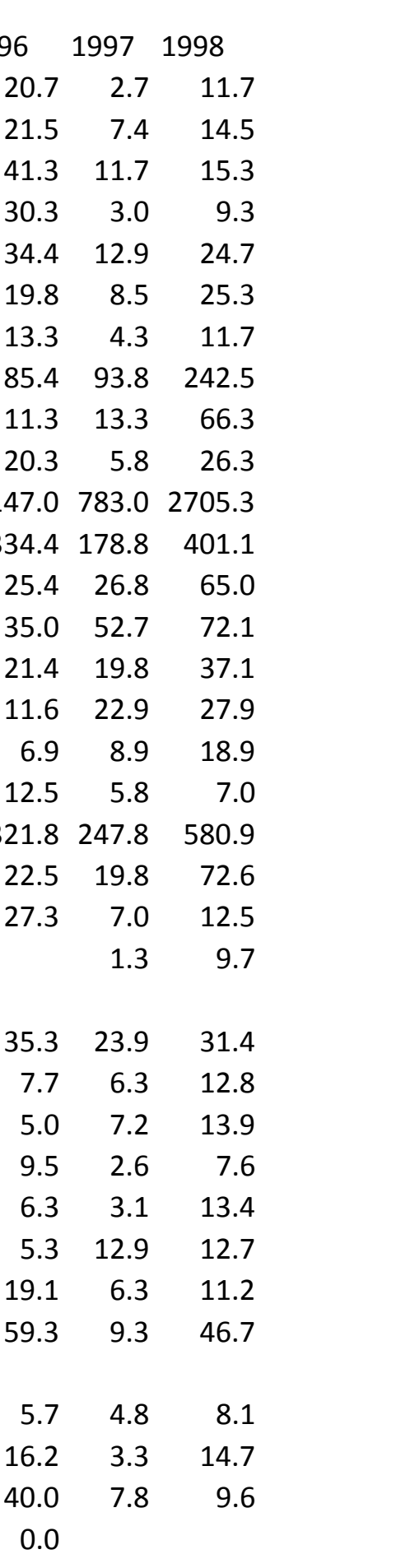

$\begin{array}{ll}-69 & 50\end{array}$

280.7

$0.3 \quad 0.0$

$0.3 \quad 15.0$

37.5

$\begin{array}{ll}7.7 & 6.4\end{array}$

2.9

$\begin{array}{lll}9.7 & 11.9 & 11.2\end{array}$

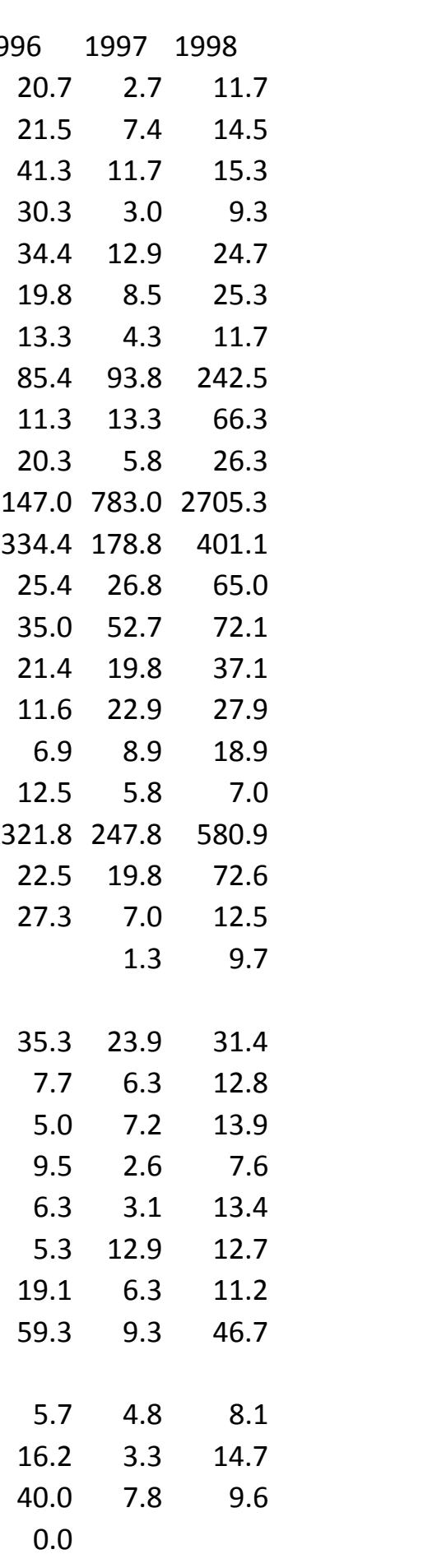

$3.1 \quad 5.8$

5.8

$1.2 \quad 2.0$

$-6848$

$47.4 \quad 32.6$

$\begin{array}{lll}2.7 & 60.0 & 261.7\end{array}$

63.8

160.1

7.2

8.7

0.4

40.0

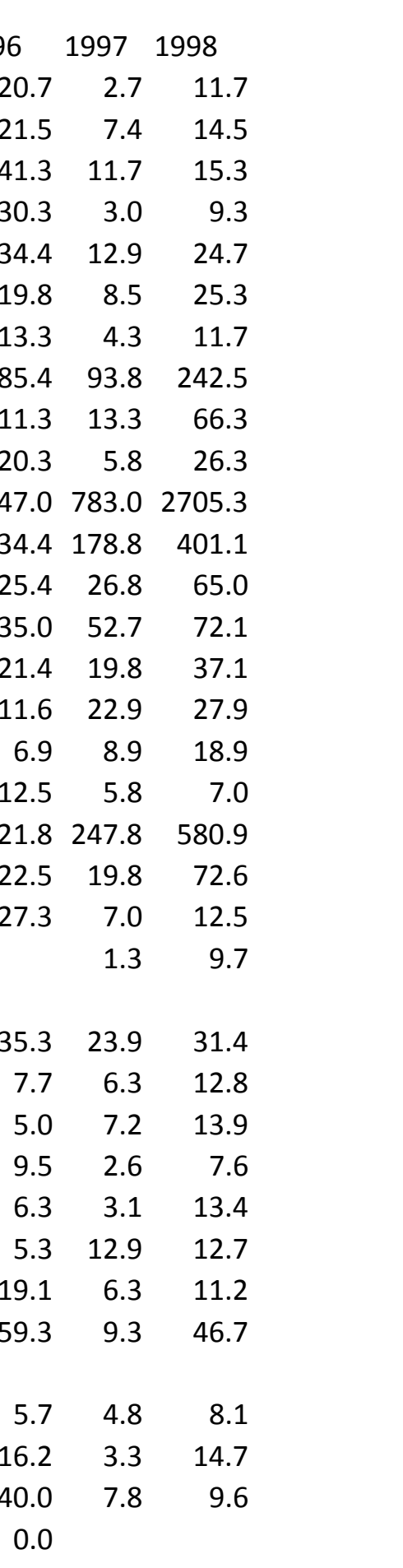

$\begin{array}{llll}-68 & 49 & 279.2 & 10.8\end{array}$

115.3

40.7

5.7

4.9

2.6

$\begin{array}{lll}5.5 & 1.3 & 2.1\end{array}$

$6.7 \quad 11.3$

3.1

7.5

$1.9 \quad 3.0$

$-67 \quad 48$
-68

$\begin{array}{lll}2.6 & 34.3 & 74.6\end{array}$

$\begin{array}{ll}1.5 & 13.8\end{array}$

8.3

7.6

5.5

7.3

36.3

3.4

3.

3.

9.3

9.7

$9.2 \quad 11.7$

$\begin{array}{rr}29.2 & 9.2 \\ 17.8 & 10.8\end{array}$

9.1

11.9

11.

$\begin{array}{lll}1.3 & 1.7 & 1.0\end{array}$ 


$\begin{array}{rrrrrrrrrrrrrrr}-67 & 49 & 80.6 & 7.0 & 5.4 & 114.0 & 5.5 & 32.5 & 22.0 & 2.3 & 2.4 & 15.2 & 10.3 & 1.4 & 0.7 \\ -67 & 50 & & & & & & 24.7 & 22.7 & 2.7 & 1.5 & 3.3 & 2.7 & 0.3 & 1.0 \\ -66 & 48 & 78.5 & 53.5 & 218.7 & 376.5 & 55.4 & 220.1 & 80.9 & 11.3 & 8.9 & 4.5 & 3.7 & 0.8 & 1.3 \\ -66 & 49 & 154.5 & 12.7 & 18.8 & 139.3 & 11.3 & 52.7 & 47.8 & 7.9 & 3.2 & 9.1 & 5.5 & 1.2 & 0.5 \\ -65 & 48 & & & & & 20.2 & 290.8 & 102.9 & 19.7 & 5.1 & 4.0 & 3.3 & 0.2 & 0.0 \\ -65 & 49 & 23.7 & 1.0 & 0.3 & 83.3 & 6.7 & 36.5 & 39.7 & 8.3 & 4.6 & 6.7 & 1.0 & 0.9 & 0.8 \\ -64 & 48 & & & & & 40.7 & 178.3 & 42.7 & 16.0 & 4.0 & 2.3 & 0.0 & 0.0 & 0.0 \\ -64 & 49 & 7.7 & 0.3 & 2.3 & 90.7 & 5.3 & 37.5 & 33.0 & 23.0 & 1.3 & 4.0 & 2.0 & 0.3 & 0.7 \\ -62 & 47 & & & & & & & & 349.9 & 107.4 & 304.6 & 145.8 & 5.9 & 1.2\end{array}$




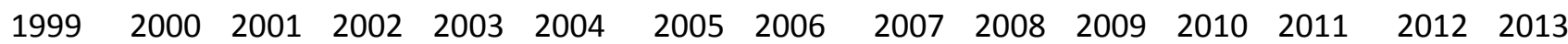

$\begin{array}{lllllllllllllll}67.3 & 101.0 & 54.7 & 20.3 & 19.3 & 35.3 & 197.0 & 155.3 & 50.7 & 47.7 & 34.0 & 55.0 & 25.7 & 19.0 & 42.7\end{array}$

$\begin{array}{lllllllllllllll}34.7 & 40.9 & 35.2 & 21.6 & 64.4 & 39.7 & 56.7 & 515.3 & 252.4 & 167.8 & 294.9 & 192.8 & 381.3 & 366.1 & 324.0\end{array}$

$\begin{array}{lllllllllllllll}55.0 & 50.3 & 51.0 & 19.0 & 13.3 & 23.7 & 46.3 & 566.7 & 232.3 & 113.7 & 34.3 & 82.0 & 78.3 & 118.5 & 94.7\end{array}$

$\begin{array}{lllllllllllllll}62.0 & 50.7 & 24.0 & 12.7 & 10.0 & 15.0 & 15.8 & 82.8 & 60.1 & 34.2 & 24.3 & 29.7 & 41.8 & 10.1 & 41.5\end{array}$

$\begin{array}{lllllllllllllll}26.6 & 23.3 & 41.7 & 8.5 & 14.8 & 13.9 & 46.5 & 112.3 & 44.8 & 91.3 & 35.7 & 31.1 & 86.0 & 66.2 & 44.3\end{array}$

$\begin{array}{lllllllllllllll}33.5 & 32.3 & 49.2 & 19.7 & 41.4 & 13.0 & 37.8 & 120.1 & 109.3 & 106.7 & 34.6 & 55.8 & 113.4 & 120.1 & 72.1\end{array}$

$\begin{array}{lllllllllllllll}6.7 & 38.3 & 30.7 & 4.7 & 6.7 & 9.3 & 19.0 & 36.0 & 12.3 & 47.3 & 27.0 & 28.0 & 48.7 & 48.0 & 56.3\end{array}$

$\begin{array}{lllllllllllllll}304.1 & 201.8 & 220.1 & 311.5 & 444.1 & 357.7 & 256.5 & 297.2 & 209.0 & 146.9 & 112.1 & 63.8 & 61.2 & 62.9 & 73.3\end{array}$

$\begin{array}{lllllllllllllll}47.5 & 43.0 & 39.3 & 21.8 & 33.5 & 23.0 & 11.3 & 55.6 & 27.8 & 56.8 & 22.1 & 27.3 & 27.2 & 38.3 & 73.2\end{array}$

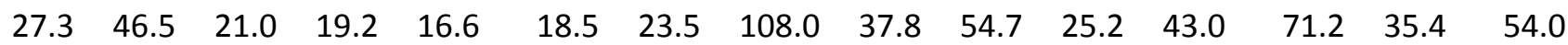

$\begin{array}{lllllllllllllll}1072.0 & 525.0 & 524.7 & 156.6 & 505.7 & 1012.7 & 471.3 & 1150.0 & 339.0 & 201.7 & 110.5 & 88.3 & 163.5 & 54.3 & 150.0\end{array}$

$\begin{array}{lllllllllllllll}53.2 & 48.8 & 25.8 & 21.6 & 38.6 & 90.1 & 18.9 & 161.8 & 66.9 & 54.8 & 31.7 & 94.7 & 37.2 & 27.2 & 38.3\end{array}$

$\begin{array}{lllllllllllllll}68.5 & 47.2 & 45.8 & 20.1 & 46.5 & 85.8 & 20.4 & 71.3 & 39.4 & 25.3 & 16.2 & 28.3 & 26.4 & 5.0 & 12.7\end{array}$

$\begin{array}{lllllllllllllll}51.8 & 76.0 & 27.2 & 33.8 & 39.9 & 102.5 & 39.7 & 121.2 & 29.7 & 34.8 & 17.7 & 57.4 & 39.6 & 11.7 & 13.6\end{array}$

$\begin{array}{lllllllllllllll}33.0 & 51.1 & 51.6 & 41.0 & 34.2 & 45.2 & 17.2 & 78.1 & 35.3 & 30.3 & 13.2 & 25.8 & 53.2 & 9.7 & 8.6\end{array}$

$\begin{array}{lllllllllllllll}21.6 & 39.5 & 16.5 & 11.3 & 14.5 & 17.3 & 2.0 & 25.2 & 15.2 & 6.7 & 4.9 & 26.3 & 20.6 & 8.3 & 9.3\end{array}$

$\begin{array}{lllllllllllllll}14.5 & 21.5 & 14.8 & 6.5 & 11.8 & 20.2 & 3.3 & 47.8 & 19.3 & 10.0 & 11.7 & 17.4 & 21.0 & 6.0 & 31.3\end{array}$

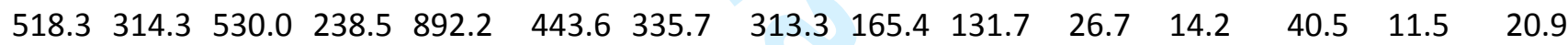

$\begin{array}{lllllllllllllll}73.3 & 123.1 & 187.5 & 201.1 & 612.2 & 207.1 & 74.9 & 82.7 & 124.8 & 164.9 & 121.7 & 107.3 & 189.4 & 87.9 & 111.5\end{array}$

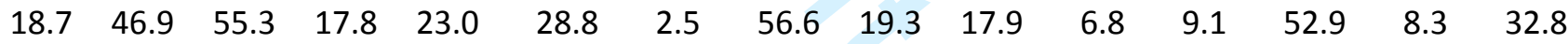

$\begin{array}{lllllllllllllll}16.0 & 37.3 & 18.8 & 7.7 & 25.8 & 84.5 & 73.5 & 647.7 & 148.7 & 109.2 & 14.8 & 32.3 & 201.3 & 37.8 & 146.8\end{array}$

$\begin{array}{lllllllllllll}1.7 & 1.4 & 7.2 & 14.3 & 9.7 & 70.0 & 30.5 & 29.5 & 43.2 & 3.5 & 4.0 & 45.2 & 9.0\end{array}$

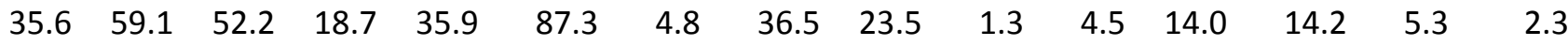

$\begin{array}{lllllllllllllll}11.7 & 23.2 & 18.2 & 10.1 & 10.7 & 27.4 & 7.4 & 23.6 & 26.8 & 1.9 & 0.3 & 12.6 & 13.3 & 5.1 & 3.6\end{array}$

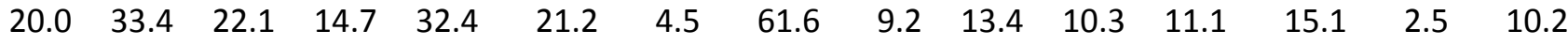

$\begin{array}{lllllllllllllll}9.2 & 24.3 & 22.7 & 13.6 & 42.7 & 47.8 & 25.9 & 195.1 & 133.4 & 132.0 & 378.7 & 195.0 & 417.2 & 153.8 & 134.7\end{array}$

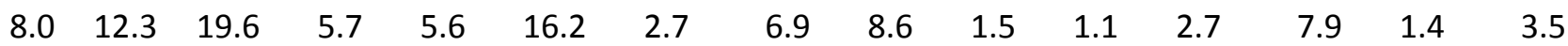

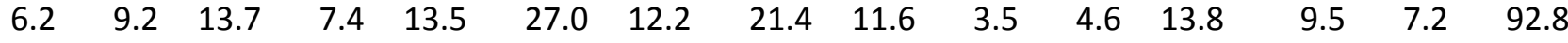

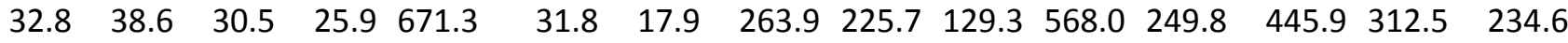

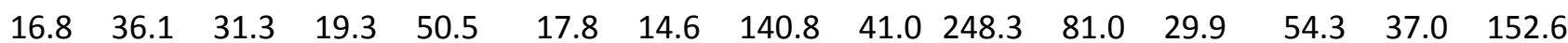

$\begin{array}{lllllllllllllll}6.0 & 9.7 & 6.3 & 2.7 & 1.3 & 3.7 & 0.0 & 2.0 & 3.0 & 1.3 & 0.0 & 1.7 & 3.7 & 0.0 & 4.7\end{array}$

$\begin{array}{rrrrrrrrrrrrrrr}6.4 & 10.0 & 15.7 & 5.4 & 15.0 & 8.7 & 7.0 & 14.3 & 22.1 & 6.2 & 5.8 & 14.0 & 26.0 & 7.4 & 164.1\end{array}$

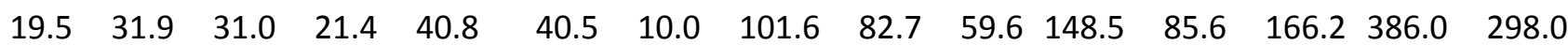

$\begin{array}{lllllllllllllll}12.3 & 22.0 & 28.4 & 9.1 & 21.8 & 31.3 & 6.7 & 87.7 & 34.3 & 180.1 & 177.0 & 105.5 & 295.2 & 48.4 & 320.7\end{array}$

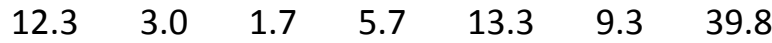

$\begin{array}{lllllllllllllll}3.9 & 6.9 & 4.6 & 4.0 & 4.1 & 1.4 & 1.2 & 21.2 & 20.4 & 11.4 & 13.7 & 14.1 & 50.3 & 49.5 & 241.3\end{array}$

$\begin{array}{lllllllllllllll}5.2 & 13.3 & 24.1 & 12.5 & 29.0 & 42.6 & 13.5 & 218.8 & 58.6 & 192.3 & 245.6 & 165.7 & 849.0 & 783.3 & 1716.3\end{array}$

$\begin{array}{llllllllllllllll}11.0 & 18.7 & 51.0 & 40.0 & 76.3 & 97.7 & 42.0 & 306.7 & 170.7 & 546.0 & 335.3 & 146.2 & 300.7 & 496.0 & 1766.2\end{array}$

$\begin{array}{lllllllllllllll}1.0 & 1.7 & 2.2 & 1.4 & 2.9 & 0.6 & 0.4 & 8.3 & 3.4 & 4.3 & 8.0 & 14.8 & 129.5 & 38.7 & 233.4\end{array}$

$\begin{array}{lllllllllllllll}1.3 & 4.2 & 6.2 & 4.3 & 5.2 & 13.3 & 8.3 & 162.8 & 326.3 & 103.2 & 357.9 & 511.8 & 590.3 & 685.5 & 519.5\end{array}$

$\begin{array}{lllllllllllllll}1.2 & 2.6 & 3.0 & 2.0 & 4.9 & 1.6 & 0.5 & 8.4 & 2.0 & 2.3 & 5.4 & 7.9 & 153.8 & 69.9 & 159.6\end{array}$ 


$\begin{array}{rrrrrrrrrrrrrrr}2.2 & 2.3 & 3.7 & 2.5 & 5.5 & 4.5 & 1.4 & 21.8 & 5.7 & 7.4 & 18.4 & 58.4 & 246.1 & 284.8 & 499.1 \\ 1.5 & 6.0 & 2.0 & 8.0 & 5.7 & 14.7 & 6.7 & 88.0 & 201.9 & 484.5 & 97.7 & 152.2 & 1317.6 & 867.5 & 1611.7 \\ 1.3 & 9.2 & 7.3 & 3.8 & 6.3 & 2.1 & 0.9 & 7.8 & 3.5 & 1.8 & 6.1 & 4.5 & 27.5 & 20.1 & 58.5 \\ 0.7 & 1.8 & 3.4 & 2.8 & 3.9 & 4.6 & 3.2 & 29.3 & 6.0 & 13.4 & 33.9 & 75.0 & 234.5 & 445.4 & 668.9 \\ 0.3 & 1.5 & 2.2 & 1.3 & 1.3 & 0.5 & 0.2 & 4.0 & 1.3 & 1.2 & 4.3 & 7.0 & 20.8 & 12.4 & 63.4 \\ 1.1 & 2.2 & 4.6 & 2.7 & 6.8 & 4.0 & 4.3 & 36.1 & 13.6 & 30.8 & 23.0 & 61.5 & 178.2 & 169.7 & 333.4 \\ 0.7 & 0.0 & 0.0 & 0.3 & 0.0 & 0.0 & 0.0 & 1.7 & 1.0 & 11.0 & 28.5 & 15.0 & 80.0 & 144.0 & 49.0 \\ 4.0 & 5.0 & 4.3 & 1.7 & 1.8 & 0.2 & 0.0 & 7.7 & 2.5 & 5.5 & 29.2 & 5.3 & 49.2 & 21.8 & 86.5 \\ 1.1 & 3.3 & 6.5 & 7.9 & 4.0 & & 0.5 & 11.4 & 1.3 & 5.2 & 3.6 & 6.1 & & 82.5 & 56.7\end{array}$




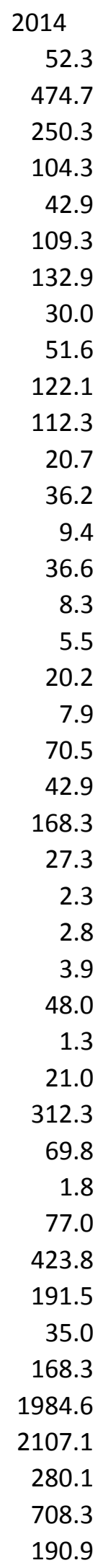

8.3

5.5

20.2

7.9

70.5

42.9

168.3

27.3

2.3

2.8

3.9

48.0

1.3

21.0

312.3

69.8

1.8

77.0

423.8

191.5

35.0

168.3

1984.6

2107.1

280.1

708.3

190.9 
619.4

2052.8

38.3

546.7

18.6

391.1

11.5

63.2 
Supplementary material 2

Number of plots located in each cell (three pheromone traps are present in each plot).

LON LAT 1986198719881989199019911992199319941995199619971998199920002001

$-80 \quad 48$

$\begin{array}{ll}-79 & 47\end{array}$

$\begin{array}{rr}-79 & 48\end{array}$

$\begin{array}{ll}-79 & 49\end{array}$

$-78 \quad 46$

$\begin{array}{ll}-78 & 47 \\ -78 & 48\end{array}$

$-78 \quad 48$

$-77 \quad 46$

$\begin{array}{ll}-77 & 47\end{array}$

$\begin{array}{ll}-77 \quad 48 \\ -76 & 45\end{array}$

$\begin{array}{ll}-76 & 45\end{array}$

$-76 \quad 46$

$\begin{array}{ll}-76 & 47\end{array}$

$\begin{array}{ll}-75 & 46\end{array}$

$-75 \quad 47$

$-74 \quad 46$

$\begin{array}{ll}-74 & 47\end{array}$

$\begin{array}{ll}-74 & 48\end{array}$

$-734$

$\begin{array}{ll}-73 & 47\end{array}$

$\begin{array}{ll}-73 & 48\end{array}$

$\begin{array}{ll}-73 & 49\end{array}$

$\begin{array}{ll}-73 \quad 50 \\ -72 & 45\end{array}$

$\begin{array}{ll}-72 \quad 45 \\ -72 & 46\end{array}$

$\begin{array}{ll}-72 \quad 46 \\ -72 & 47\end{array}$

$-724$

$\begin{array}{ll}-72 & 48\end{array}$

$\begin{array}{ll}-71 & 46\end{array}$

$-71 \quad 47$

$\begin{array}{ll}-71 & 48\end{array}$

$\begin{array}{ll}-71 & 49\end{array}$

$\begin{array}{ll}-70 & 46\end{array}$

$\begin{array}{lllllll}-70 & 47 & 1 & 1 & 1 & 1 & 5\end{array}$

$\begin{array}{llllllllllllllllll}-70 & 48 & 1 & 1 & 1 & 1 & 4 & 5 & 5 & 5 & 5 & 5 & 6 & 6 & 6 & 7 & 8 & 7\end{array}$

$\begin{array}{llllllllllllllllll}-70 & 49 & 1 & 1 & 1 & 1 & 3 & 3 & 3 & 3 & 2 & 2 & 1 & 2 & 2 & 3 & 3 & 3\end{array}$

$\begin{array}{ll}-69 & 47\end{array}$

$\begin{array}{lllllll}-69 & 48 & 3 & 3 & 3 & 4 & 6\end{array}$

$\begin{array}{lllllll}-69 & 49 & 1 & 1 & 1 & 1 & 3\end{array}$

$-6950$

$\begin{array}{lllllll}-68 & 48 & 4 & 7 & 7 & 7 & 7\end{array}$

$\begin{array}{lllllll}-68 & 49 & 2 & 2 & 2 & 2 & 2\end{array}$

$\begin{array}{lllllllllll}1 & 1 & 1 & 1 & 1 & 1 & 1 & 1 & 1 & 1 & 1\end{array}$

$\begin{array}{lllllllllll}5 & 6 & 4 & 4 & 4 & 4 & 4 & 4 & 4 & 4 & 4\end{array}$

$\begin{array}{lllllllllll}1 & 1 & 1 & 1 & 1 & 1 & 1 & 1 & 1 & 1 & 1\end{array}$

$\begin{array}{llllllllllll}2 & 3 & 3 & 3 & 3 & 3 & 3 & 3 & 3 & 3 & 3 & 3\end{array}$

$\begin{array}{lllllllllll}2 & 3 & 4 & 4 & 4 & 4 & 4 & 4 & 4 & 4 & 4\end{array}$

$\begin{array}{lllllllllll}1 & 1 & 1 & 1 & 1 & 1 & 1 & 1 & 1 & 1 & 1\end{array}$

$\begin{array}{lllllllllll}9 & 10 & 9 & 10 & 10 & 10 & 9 & 9 & 8 & 9 & 9\end{array}$

$\begin{array}{lllllllllll}2 & 2 & 2 & 2 & 2 & 2 & 2 & 2 & 2 & 2 & 2\end{array}$

$\begin{array}{rrrrrrrrrrrrrrrr}1 & 1 & 1 & 1 & 1 & 1 & 1 & 1 & 1 & 1 & 1 & 1 & 1 & 1 & 1 & 1\end{array}$

$\begin{array}{lllllllrrrrrrrr}3 & 3 & 3 & 3 & 3 & 3 & 3 & 3 & 3 & 3 & 3 & 3 & 3 & 3 & 3\end{array}$

$\begin{array}{llllllllllllllll}5 & 5 & 8 & 8 & 8 & 8 & 7 & 8 & 8 & 8 & 8 & 8 & 8 & 9 & 9 & 8\end{array}$

$\begin{array}{llllllllllllllll}2 & 2 & 1 & 3 & 3 & 3 & 3 & 3 & 3 & 3 & 3 & 3 & 3 & 3 & 3 & 3\end{array}$

$\begin{array}{lllllllllllllll}3 & 3 & 3 & 5 & 6 & 6 & 6 & 6 & 6 & 6 & 5 & 5 & 6 & 6 & 6\end{array}$

$\begin{array}{lllllllllllllll}1 & 1 & 1 & 1 & 2 & 2 & 2 & 2 & 2 & 2 & 2 & 2 & 2 & 2 & 2\end{array}$ 


$\begin{array}{llllllllllllllllll}-67 & 49 & 4 & 4 & 3 & 4 & 5 & 5 & 5 & 5 & 5 & 3 & 4 & 3 & 3 & 3 & 3 & 2 \\ -67 & 50 & & & & & & 1 & 1 & 1 & 1 & 1 & 1 & 1 & 1 & 1 & 1 & 1 \\ -66 & 48 & 2 & 2 & 2 & 2 & 3 & 3 & 4 & 4 & 5 & 6 & 6 & 6 & 6 & 6 & 6 & 6 \\ -66 & 49 & 5 & 5 & 5 & 5 & 7 & 7 & 6 & 6 & 6 & 7 & 8 & 6 & 9 & 5 & 5 & 9 \\ -65 & 48 & & & & & 4 & 4 & 4 & 4 & 3 & 3 & 2 & 2 & 2 & 2 & 2 & 2 \\ -65 & 49 & 1 & 1 & 1 & 1 & 4 & 4 & 4 & 4 & 4 & 4 & 3 & 3 & 6 & 5 & 6 & 6 \\ -64 & 48 & & & & & 1 & 1 & 1 & 1 & 1 & 1 & 1 & 1 & 1 & 1 & 1 & 1 \\ -64 & 49 & 1 & 1 & 1 & 1 & 1 & 1 & 1 & 1 & 1 & 1 & 1 & 1 & 1 & 1 & 1 & 1 \\ -62 & 47 & & & & & & & & 3 & 3 & 4 & 3 & 3 & 3 & 3 & 4 & 4\end{array}$


2002200320042005200620072008200920102011201220132014

$\begin{array}{rrrrrrrrrrrrr}1 & 1 & 1 & 1 & 1 & 1 & 1 & 1 & 1 & 1 & 1 & 1 & 1 \\ 4 & 4 & 4 & 4 & 7 & 6 & 4 & 4 & 3 & 3 & 3 & 10 & 12 \\ 1 & 1 & 1 & 1 & 1 & 1 & 1 & 1 & 1 & 1 & 1 & 12 & 15 \\ 1 & 1 & 2 & 2 & 3 & 3 & 3 & 3 & 3 & 3 & 3 & 4 & 4 \\ 2 & 3 & 3 & 2 & 3 & 3 & 2 & 2 & 2 & 2 & 2 & 5 & 5 \\ 5 & 4 & 4 & 4 & 5 & 5 & 4 & 3 & 3 & 3 & 3 & 6 & 6 \\ 1 & 1 & 1 & 1 & 1 & 1 & 1 & 1 & 1 & 1 & 1 & 6 & 7 \\ 11 & 13 & 9 & 9 & 9 & 9 & 9 & 8 & 9 & 8 & 9 & 13 & 14 \\ 2 & 2 & 2 & 2 & 2 & 3 & 3 & 3 & 3 & 3 & 3 & 8 & 8 \\ 2 & 2 & 2 & 2 & 2 & 2 & 2 & 2 & 2 & 2 & 2 & 2 & 4 \\ 2 & 1 & 1 & 1 & 1 & 1 & 1 & 1 & 1 & 1 & 1 & 1 & 1 \\ 16 & 21 & 13 & 13 & 12 & 12 & 12 & 12 & 12 & 9 & 9 & 11 & 12 \\ 3 & 3 & 3 & 3 & 3 & 3 & 3 & 2 & 3 & 2 & 2 & 7 & 8 \\ 9 & 9 & 9 & 9 & 9 & 9 & 9 & 9 & 9 & 9 & 9 & 12 & 15 \\ 3 & 3 & 3 & 3 & 3 & 3 & 3 & 3 & 3 & 3 & 3 & 7 & 7 \\ 7 & 6 & 6 & 7 & 7 & 7 & 7 & 7 & 7 & 7 & 7 & 10 & 10 \\ 5 & 5 & 5 & 4 & 4 & 4 & 4 & 4 & 4 & 3 & 3 & 8 & 9 \\ 2 & 2 & 2 & 2 & 2 & 2 & 2 & 2 & 2 & 2 & 1 & 2 & 3 \\ 5 & 5 & 4 & 4 & 4 & 4 & 4 & 4 & 2 & 2 & 4 & 4 & 3 \\ 17 & 19 & 17 & 17 & 17 & 17 & 17 & 17 & 17 & 13 & 17 & 17 & 15 \\ 5 & 4 & 4 & 4 & 4 & 4 & 4 & 4 & 4 & 4 & 3 & 7 & 8 \\ 2 & 2 & 2 & 2 & 2 & 2 & 2 & 2 & 2 & 1 & 2 & 6 & 6 \\ 2 & 2 & 2 & 2 & 2 & 2 & 2 & 2 & 2 & 1 & 2 & 1 & 2 \\ 4 & 4 & 4 & 4 & 4 & 4 & 3 & 4 & 4 & 4 & 4 & 7 & 7 \\ 3 & 3 & 3 & 3 & 3 & 3 & 3 & 3 & 3 & 3 & 3 & 6 & 7 \\ 8 & 8 & 8 & 8 & 8 & 8 & 8 & 8 & 8 & 6 & 8 & 11 & 11 \\ 3 & 3 & 3 & 3 & 3 & 3 & 3 & 3 & 2 & 3 & 3 & 8 & 8 \\ 5 & 1 & 1 & 1 & 1 & 1 & 1 & 1 & 2 & 1 & 1 & 2 & 3 \\ 9 & 9 & 9 & 9 & 9 & 9 & 8 & 8 & 8 & 8 & 8 & 12 & 15 \\ 2 & 2 & 2 & 2 & 2 & 4 & 2 & 2 & 2 & 2 & 2 & 8 & 8 \\ 7 & 7 & 7 & 8 & 8 & 8 & 8 & 8 & 8 & 8 & 8 & 8 & 12\end{array}$




$\begin{array}{rrrrrrrrrrrrr}7 & 7 & 7 & 7 & 7 & 9 & 9 & 8 & 8 & 8 & 8 & 12 & 11 \\ 1 & 1 & 1 & 1 & 1 & 4 & 4 & 2 & 2 & 2 & 2 & 4 & 4 \\ 6 & 6 & 6 & 6 & 6 & 7 & 7 & 7 & 7 & 7 & 7 & 7 & 7 \\ 10 & 10 & 10 & 10 & 10 & 9 & 9 & 8 & 10 & 10 & 10 & 13 & 14 \\ 3 & 3 & 2 & 3 & 3 & 3 & 3 & 3 & 3 & 3 & 3 & 4 & 4 \\ 8 & 8 & 8 & 8 & 8 & 8 & 7 & 8 & 8 & 7 & 7 & 9 & 13 \\ 1 & 1 & 1 & 1 & 1 & 1 & 1 & 1 & 1 & 1 & 1 & 1 & 1 \\ 2 & 2 & 2 & 2 & 2 & 2 & 2 & 2 & 2 & 2 & 2 & 2 & 2 \\ 4 & 4 & & 4 & 4 & 4 & 4 & 3 & 3 & & 3 & 3 & \end{array}$


Supplementary material 3

White spruce cone collection data in Québec for the 198 Plants Forestiers (Quebec Government). Because the quc tree farms during any given year or period, the qualitativ

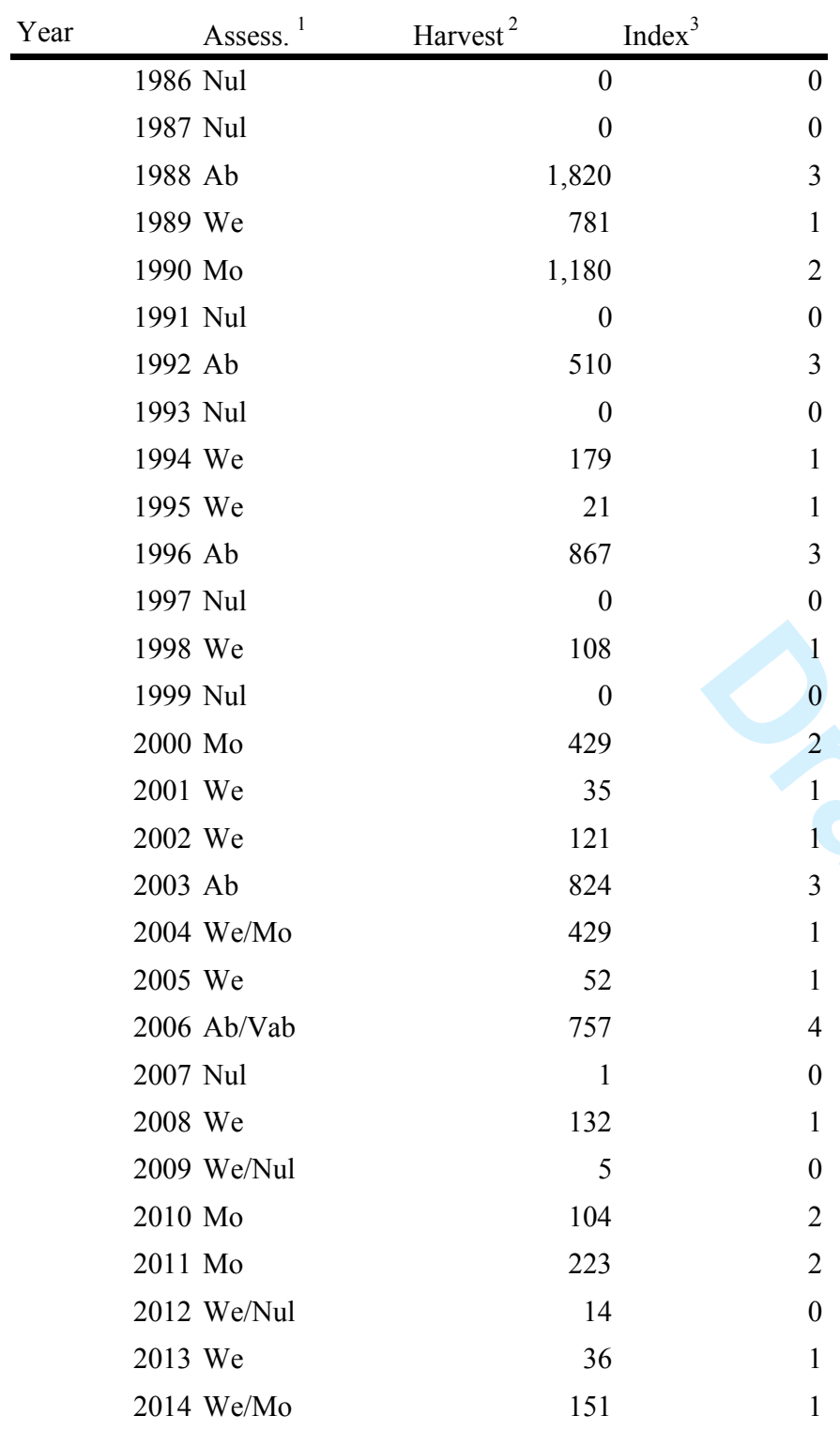

Notes:

1 Overall province-level semi-quantitative assessment made ea 2 Volume of cones harvested, in hectolitres ( $1 \mathrm{hl}=100$ litres)

3 Quantitative index used in the analyses 
6-2014 period. Data is provided by the Direction Générale de la Production de Semences et de intitative assessment (volume of cones harvested) is somewhat biased by the demand expressed by e assessment was used as a predictor in the statistical analyses performed in this study.

ıch year: Vab : cone production very abundant, $\mathrm{Ab}$ : abundant, Mo : moderate, We : weak, Nul : nul. 